\title{
THE EFFECT OF ADOLESCENT ATTITUDES ON KARANG TARUNA IN HANDLING PROBLEMS TOWARD ADOLESCENTS IN THE DEVELOPMENT PERIOD
}

\author{
Suharma \\ Bandung Polytechnic of Social Welfare (Poltekesos), Ir. H. Juanda Street (Dago), No. 367, \\ Bandung, harmas_stks@yahoo.co.id
}

Ramli A Rahman

Bandung Polytechnic of Social Welfare (Poltekesos), Ir. H. Juanda Street (Dago), No. 367, Bandung, ramliarahman@yahoo.com

Ernalia Lia Syaodih

Bandung Polytechnic of Social Welfare (Poltekesos), Ir. H. Juanda Street (Dago), No. 367, Bandung, ernaliasyaodih@yahoo.com

Yana Sundayani

Bandung Polytechnic of Social Welfare (Poltekesos), Ir. H. Juanda Street (Dago), No. 367, Bandung, yanasundayani@yahoo.com

Popon Sutarsih

Bandung Polytechnic of Social Welfare (Poltekesos), Ir. H. Juanda Street (Dago), No. 367, Bandung, Poponsutarsih08_@yahoo.com

Yeane EM Tungga

Bandung Polytechnic of Social Welfare (Poltekesos), Ir. H. Juanda Street (Dago), No. 367, Bandung, latswork01@yahoo.com

\begin{abstract}
Adolescence is the most important development period for an individual, in fact, it is a period filled by changes and vulnerable to the emergence of the problems. Forum of Karang Taruna has a strategic role as a means of youth participation in an effort to make social adjustments so that they can deal with the problems encountered during life development. This research was conducted to gain a deep understanding and thorough about the influence of adolescent attitudes about the Karang Taruna on handling problems faced by youth in the development phase of their life. This research used a quantitative approach with a survey explanatory research population were teenagers aged 12 to 21 years. Measuring instrument research used a Likert scale. The technique of collecting data used questionnaires and documentation study. Data were analyzed using path analysis. Adolescent attitudes toward Karang Taruna have a significant effect on the involvement of adolescents in Karang Taruna activities. The amount of influence adolescent attitudes about the Karang Taruna on the involvement of adolescents in Karang Taruna amounted to $61.40 \%$. The results also showed that the attitude of teenagers towards Karang Taruna has a significant influence on the Settlement of the problems faced by an adolescent in their life development through variable among adolescent involvement in Karang Taruna. The number of adolescent attitudes influences Karang Taruna through the involvement of adolescents in Karang Taruna on the handling of problems faced by an adolescent in the developmental period of their life amounted to $85.80 \%$. Karang Taruna can
\end{abstract}


be used as a means to develop the activity and creativity of adolescents in handling the problems encountered in the development phase of their life. However, there are six main problems faced by Karang Taruna including; (1) an inactive member; (2); a caretaker capacity in managing Karang Taruna; (3) there is no clear work programme; (4) The board of Karang Taruna inactivity; (5) the absence of funding sources; and (6) less variation in the activities of Karang Taruna that does not appeal to its members, especially for passive members.

\section{Keywords:}

Attitude, Adolescent, Social Participation, Karang Taruna, Adolescent's Problem 


\section{INTRODUCTION}

Adolescence is the most important development period for individuals is, in fact, a period that which filled by changes and vulnerable to the emergence of problems. Adolescence is a period of identity crisis or the search for self-identity. Every period of human life has its own problems, including the teenage period. Teenagers in general experience that the search for identity or integrity is a major problem because of social, physiological and psychological changes in themselves and in the communities in which they live.

Teenagers are those who are at the age of 12-18 years (Hurlock, 1981). On the other hand, Monks (2000) gives a limit on the age of adolescents is 12-21 years. According to Stanley Hall in Santrock (2003), adolescents are in the range of 12-23 years. Based on the limitations given by experts, it can be seen that the start of adolescence is relatively the same, but the end of adolescence varies greatly.

According to Erickson adolescence is a period of identity crisis or the search for selfidentity. Erickson's idea was corroborated by James Marcia who found that there were four statuses of identity in adolescents namely identity diffusion/confusion, moratorium, foreclosure, and identity achieved (Santrock, 2003; Monks, 2000). Characteristics of adolescents who are in the process of searching for self-identity also often cause problems in adolescents. Gunarsa (1989) summarizes some of the characteristics of adolescents that can cause various problems in adolescents, namely: (1) awkwardness in association and rigidity in movement; (2) emotional instability; (3) there is an empty feeling due to reshuffle of outlook and life direction; (4) the existence of resistance and challenge to parents; (5) conflicts within themselves often become the root cause of conflicts with parents; (6) anxiety because many things are desirable but adolescents are unable to fulfill all of them; (7) happy to experiment; (8) enjoy exploring; (9) has many fantasies, delusions, and boasting; and (10) tendencies to form groups and tendencies to group activities.

Based on a review of development theory, adolescence is a time of rapid changes, including fundamental changes in cognitive, emotional, social and achievement aspects (Fagan, 2006). Some adolescents are able to cope with this transition well, but some teenagers may experience a decline in psychological, physiological, and social conditions. Some adolescent problems that arise are usually a lot related to the characteristics that exist in adolescents. Fagan (2006) mentions some of the main problems experienced by adolescents, including;

1. Social and interpersonal influences: including lack of warmth from parents, supervision, control, and encouragement. Negative assessment from parents, tension at home, divorce, and separation from parents.

2. Cultural and manners influences: viewing alcohol and drugs as a symbol of a rejection of conventional standards, oriented towards short-term goals and hedonic satisfaction, etc.

3. Personal influences: including temperamental, aggressive personalities, people who have an external locus of control, low self-esteem, poor coping skills, etc..

4. Love and heterosexual relationships.

5. Sexual problems. 
6. Adolescent relationships with parents.

7. Moral issues, values, and religion.

The use of alcohol and illegal drugs has been very concerning lately. Although efforts to stop it have been encouraged, cases of drug use do not seem to be diminishing. There are peculiarities why teens use drugs/drugs which may be the reason they use different from the reasons that occur in adults. Santrock (2003) found several reasons why adolescents consume drugs namely because of curiosity, to increase self-confidence, solidarity, adaptation to the environment, and to compensate.

On the other hand, Smith \& Anderson in Fagan (2006) states that most adolescents engage in risky behavior using drugs as part of the normal development process. The most frequent risk behavior carried out by adolescents is the use of cigarettes, alcohol, and drugs (Rey, 2002).

Many parents and educators are worried that their children, especially teenagers, will experience moral degradation. While adolescents themselves are also often faced with moral dilemmas so that adolescents feel confused about the moral decisions that must be taken. Even though their values have been implanted in their families, but adolescents will feel confused when faced with the fact that these values are very different from the values faced with their friends and in different environments (Putranti, 2009).

Furthermore, Putriani (2009) argues that the supervision of behavior by adults is difficult for adolescents because the environment of adolescents is very broad. Sharpening the conscience as an internal controller of adolescent behavior becomes very important so that adolescents can control their own behavior when there are no parents or teachers and immediately realize and correct themselves when they do wrong.

Every period of human life has its own problems, including the teenage period. Teenagers are often difficult to overcome their problems. There are two reasons for that happening, namely; First, when they were children, all their problems were always overcome by adults. This is what makes teenagers do not have experience in dealing with problems. Second, because adolescents feel themselves to be independent, then they have prestige and refuse assistance from adults (Putranti, 2009). Furthermore, Putriani (2009) suggested various problems faced by today's youth, including;

1. The need for exemplary figures. Teenagers are far more easily impressed by the noble values that take place from the example of their parents than just good advice that remains only beautiful words.

2. Apathetic attitude. Apathy is a tendency to reject something and at the same time not want to get involved in it. This apathy is manifested in his ignorance of what is happening in his society.

3. Anxiety and lack of self-esteem. The word stress or frustration is increasingly common among teenagers. Many young people try to overcome their anxiety in the form of "escape" (chasing pleasure through alcohol, sedatives, sex, and others).

4. Inability to get involved. The tendency to intellectualize everything and economic mindset makes it difficult for teenagers to involve themselves emotionally and effectively in personal relationships and in life in society. Friendship is valued by profit or even money.

5. Feeling helpless. This feeling of 
6. helplessness arises first of all because technology has increasingly mastered the lifestyles and thinking patterns of modern society. Technology inevitably creates a technocratic society that forces us to first think about our own safety in the midst of society. Furthermore, adolescents look for "shortcuts", for example using all means to not learn but get good grades or diplomas.

7. Worship of experience. Most of the negative actions of young people with strong drinking, drugs, and sex, in the beginning, started with just experimenting. The social environment of young people today gives a wrong view of the experience.

Juvenile delinquency is one of the very serious social problems that is being faced by the Indonesian people today. This social problem is often associated with problems of deviant behavior and even a violation of the law or crime. The problem is that the perpetrators are considered to be underage, so they cannot be treated the same legally as adults. Rehabilitation efforts are considered more appropriate to overcome juvenile delinquency. This is because adolescents are the next generation who still allow the potential of their human resources to develop, so that in time they will replace the previous generation, becoming leaders of the nation. Although on the opposite side juvenile delinquency is a potential crime.

Today, juvenile delinquency is increasingly prevalent with various forms of deviant behavior. Juvenile delinquency at this time is not only in the form of skipping school, stealing petty at the store, disobedient to parents, etc., but it leads to acts of crime, such as mass fights (brawls) that cause death, rape, murder, etc. -other. There are 10 major problems of adolescents in Indonesia, namely; (1) student brawls and fights; (2) violence against children in school; (3) pornography that threatens children and adolescents; (4) Narcotics problems in children and adolescents; (5) increasing cases of HIV / AIDS among the younger generation; (6) teenage promiscuity; (7) street children; (8) malnutrition in children; (9) the low International Student Education Index Value for Indonesian students; and (10) the problem of ethical and moral degradation of adolescents (Jundarwanto, 2009).

In relation to social adjustment in adolescents, one of the most difficult developmental tasks in adolescence is a social adjustment. This adjustment must be made for the different sexes in a relationship that had never existed before and for adults outside the family and school environment. At this time adolescents spend most of their time outside the home with their peers, so that it can be understood if peers are very influential on attitudes, ways of speaking, interests, appearance, and behavior of adolescents (Iskandarsyah, 2006).

Changes in adolescent social behavior can be seen by changes in attitudes and behaviors of heterosexual relations. In this case, those who did not like the involvement of the opposite sex became like friends with the opposite sex. In general, it can be said that the interest of adolescents towards the opposite sex increases. In addition, social changes that occur with the existence of new values in choosing friends, where adolescents prefer those who have the same interests and values, can understand and make feel safe, can be trusted and can discuss things that cannot be discussed with the teacher or parent. At this time even teenagers have the desire to appear 
as someone who is popular and liked by their environment.

Conformity with peer groups has an important role for adolescents. They try to find their identity by dressing, talking and behaving as much as possible with the group. One way for teens to convince themselves is to use status symbols, such as cars, clothing and other objects that can be seen by others. Adolescence is often feared by the individual himself and the environment.

In general, adolescent problems including juvenile delinquency are carried out by children aged between 15-18 years. Adolescence is a period where the transition of childhood towards adulthood. At this time their souls are still unstable and they do not have a definite grip. They act according to their thoughts and reason, the actions they do in finding their true identity (Hata Rajasa, 2007).

Every period of human life has its own problems, including the teenage period. Adolescents in general experience that the search for identity or integrity is a major problem because of social, physiological and psychological changes in themselves and in the communities where they live. This change is coupled with exposure to changes in social and moral degradation that are increasingly complex and modern in technology. The low economic, social and educational status of parents will create problems for adolescents. Fulfillment of children's rights including the fulfillment of nutrition, education, and fulfillment of other children's needs is hampered.

The conditions faced by the Indonesian people today show that the era of globalization has placed Indonesian youth and young people in a position that is in the midst of a swift flow of information that is so free, in line with advances in information and telecommunications technology. As a result, foreign values consciously or unconsciously have a direct or indirect effect on youth and young people. Although there is still no direct empirical evidence that these foreign values have a negative impact on youth and the young generation, if no anticipatory measures are made, it is not impossible, in the future, the Indonesian Nation will become a weak nation and it is very easy to be swept away by the hustle and bustle of the dynamics of globalization, and in the end, it will be easily controlled by other nations (Hata Rajasa, 2007).

The description of the situation above gives an influence on the sense of nationality (nationalism) among adolescents. Although it has not been clearly seen yet, it must be admitted that at this time there have begun to be symptoms of a decline in enthusiasm and a sense of nationalism or nationalism among adolescents as indicated by the diminished understanding of adolescents on the history and cultural values of their own people (Hata Rajasa, 2007).

In the process of growth and development of adolescents, there are still adolescents who have problems both caused by factors from within and from outside themselves that can hamper their duties and roles in taking responsibility as the next generation. Therefore, existing youth problems must be addressed, prevented and controlled as early as possible so as not to develop into a greater crime that can harm themselves, the community and the future of the nation.

The presence of Karang Taruna in the village as a forum for community 
participation, especially youth and young people in the field of social welfare should be felt by the community, especially for young people and young people. Karang Taruna is a social organization, a social association formed by the community that functions as a means of community participation in carrying out Social Welfare Enterprises (UKS). As a forum for the development of the younger generation, Karang Taruna is a place where various efforts or activities are held to improve and develop the creativity, taste, initiative, and work of the younger generation in the framework of developing human resources (HR) Decree of the Minister of Social Affairs No. 83 / HUK / 2005).

Karang Taruna grows and develops on the basis of an awareness of the circumstances and problems in the environment and the existence of social responsibility to participate in trying to handle it. Social awareness and responsibility are the basic capital for the growth and development of Karang Taruna. Karang Taruna grows and develops from the younger generation, managed or managed by the younger generation and for the benefit of the younger generation and the community in the village or equivalent customary community. Therefore, each village or customary community can equal grow and develop its own Karang Taruna. Its movement in the field of Social Welfare Enterprises means that all program and activity efforts organized by Karang Taruna are aimed at realizing the social welfare of the community, especially the younger generation.

Karang Taruna has a strategic role as a means of community participation in social welfare efforts and in the development of young people. This is based on the reality of the development of social welfare issues, especially those faced by the younger generation, which is increasingly complex, including issues of employment/unemployment, neglect, social disability, disability and behavioral problems that are not in accordance with national cultural values. In this context, the Karang Taruna was formed as an effort to minimize juvenile delinquency. Karang Taruna was formed as a solution for adolescents and young people to develop their abilities in efforts to meet the needs of adolescents.

There is a presumption that the involvement of adolescents in Karang Taruna has a significant correlation with the adolescent attitude towards Karang Taruna. In this case, adolescent attitudes towards the Karang Taruna will have a direct impact on the level of involvement of youth in the implementation of Karang Taruna activities. If adolescent attitudes towards Karang Taruna are low or poor, it will be followed by a low level of youth participation in Karang Taruna activities. Conversely, if the attitude of adolescents towards Karang Taruna is high or good, it will be followed by a high level of youth participation in Karang Taruna activities. When adolescents are involved in Karang Taruna, the problems faced by adolescents during their developmental period will be handled. Therefore, the better the attitude of adolescents towards Karang Taruna, the problems faced by adolescents in dealing with the development of their lives are increasingly handled. The worse the attitude of adolescents towards social organization Karang Taruna, the problems faced by adolescents are difficult in dealing with the development of their lives is difficult to handle.

Attitude is a process that makes a 
person choose, organize and interpret the stimuli received into a meaningful and complete picture of his world. Attitudes arise because of stimuli (stimuli) from outside which will affect a person through the five senses. The stimulus will be selected, organized and interpreted by everyone in their own way. Based on this, it can be seen that attitudes can arise due to external stimuli that will suppress a person's sensory nerves and through the five senses namely, vision, hearing, smell, feeling and touch, then the stimuli will be selected (Schiffman \& Kanuk, 1993).

Referring to the opinion of Feigi in Yusuf (1991), the process of forming adolescent attitudes towards the Karang Taruna as the meaning of the observations of adolescents begins with a stimulus about Karang Taruna. After getting a stimulus, the next step is a selection that interacts with interpretation. The selection process occurs when a teenager obtains information about Karang Taruna and its activities, the process of selecting messages about which messages are considered important and not important will take place. The selection process will be arranged into a sequential and meaningful unity, while the interpretation takes place when the person concerned gives an interpretation or meaning to the information as a whole. Based on the process of forming these attitudes, it can be concluded about the high or low levels of adolescent attitudes towards the Karang Taruna.

The interpretation phase in the formation of attitudes, past or past experiences plays an important role. Functional factors that determine a person's attitude come from needs, past experience and other things including those referred to as personal factors.
Based on this, there are two factors that can determine the level of adolescent attitudes about the Karang Taruna, namely; factors of past experience and personal factors (personal) adolescents.

Factors of adolescent past experience about the Karang Taruna which influence adolescent attitudes about Karang Taruna, include; (1) Karang Taruna in accommodating various needs in supporting youth development; (2) the past experience of adolescents about whether or not the aspirations of adolescents are accommodated in developing their activities and creativity in the Karang Taruna; and (3) adolescent past experiences of the high and low cohesiveness of the Karang Taruna management.

As for personal factors (personal) adolescents that affect adolescent perceptions about Karang Taruna, covering; (1) the level of understanding and knowledge of adolescents about the Karang Taruna; (2) the level of support felt by adolescents from stakeholders, especially government officials, community leaders, and Karang Taruna partner organizations towards youth activities in Karang Taruna; (3) whether or not young people are interested in Karang Taruna activities; and (4) the level of youth awareness about the goals and benefits of Karang Taruna.

The involvement of adolescents in Karang Taruna activities has a significant correlation with the attitudes of adolescents towards the Karang Taruna. In this case, adolescent attitudes towards the Karang Taruna will have a direct impact on the level of involvement of youth in the implementation of Karang Taruna activities. If adolescent attitudes towards Karang Taruna are low or poor, it will be followed by a low level of 
youth participation in Karang Taruna activities. Conversely, if the attitude of adolescents toward Karang Taruna is high or good, it will be followed by a high level of youth participation in Karang Taruna activities.

Attitude is a psychological tendency expressed by someone to evaluate certain objects with a view of beneficial or detrimental (Ahmadi, 2007). Attitude is also a willingness to act and not carry out a willingness to act and is not an implementation of certain motives because the attitude is not yet an act or activity but is a predisposition to the action of a behavior (Walgito, 1981)

Attitude is a process that makes a person choose, organize and interpret the stimuli received into a meaningful and complete picture of his world. Attitudes arise because of stimuli from outside which will affect a person through the five senses. The stimulus will be selected, organized and interpreted by everyone in their own way. Based on this, it can be seen that attitudes can arise due to external stimuli that will suppress a person's sensory nerves and through the five senses namely, vision, hearing, smell, feeling and touch, then the stimuli will be selected (Schiffman and Kanuk, 1993). Attitudes are a set of opinions, interests or goals concerning the expectation of a certain type of experience, and a willingness to have a reasonable reaction. Attitude is the desire to either do or not do a certain thing to humans (Hartini \& Kartasaputra, 1992).

Based on the above opinion understanding the attitude of having certain objects such as people, behavior, concepts, situations, objects and have an assessment of something whether to agree and disagree, like and dislike, positive and negative, good and bad. Attitudes can be formed starting from the learning process that takes place gradually, this process can be obtained from a variety of personal experiences of a person with a particular object or through a process of learning from someone or someone else. According to Walgito (1981) that the formation and change of attitude will be determined by two factors namely; (1) the individual's internal factors, namely the way individuals selectively respond to their external world so that not all who come will be accepted or rejected; (2) external factors, namely circumstances that exist outside the individual which is a stimulus to form or change attitudes.

Referring to the opinion of Ahmadi (2007), that the attitude of adolescents towards the existence of Karang Taruna social organization arises because of the stimulus. The formation of adolescent attitudes is influenced by many stimuli arising from the existence of management and activities carried out by Karang Taruna in accommodating the needs of adolescents. The function of adolescent attitudes towards the existence of Karang Taruna includes; (1) to adapt so that the needs of adolescents can be accommodated through various activities in Karang Taruna; (2) as a tool to regulate adolescent behavior in Karang Taruna activities; (3) as a tool to measure various experiences of adolescents in utilizing the existence of Karang Taruna; and (4) as a tool to describe various statements related to the existence of management and activities carried out by Karang Taruna in accommodating the needs of adolescents.

The use of Karang Taruna social organization as the creativity, intention, and 
sense of youth in implementing their needs has a significant relationship with the attitudes of adolescents towards the existence of Karang Taruna social organization. Referring to the opinion of Wirawan (2002), good or bad attitudes of adolescents towards the existence of Karang Taruna are influenced by the following aspects;

1. Knowledge (cognitive aspects) of adolescents about the existence of Karang Taruna. In this context, adolescent knowledge about the existence of Karang Taruna social organization is representative of what is seen and believed by adolescents as owners of attitudes. Youth knowledge about Karang Taruna also contains the stereotyped beliefs of youth about Karang Taruna integrated with the views/opinions of adolescents regarding issues and controversial issues related to Karang Taruna existence in carrying out its activities and management.

2. The feeling aspect (affective). In this context, adolescent attitudes towards the existence of Karang Taruna are related to the emotional aspects and feelings of adolescents related to the existence of KarangTaruna. Emotional aspects and feelings are related to the benefits felt by adolescents related to the existence of Karang Taruna. In addition, related to the feelings of adolescents about being involved or not in Karang Taruna activities as well as the feelings of adolescents related to whether or not the needs of adolescents are involved in Karang Taruna activities.

3. Psychomotor aspects. In this context, adolescent attitudes towards the existence of Karang Taruna are related to the tendency to behave involved in the management and activities of Karang Taruna.

Based on various descriptions of the research theoretical framework can be described in Figure 1. below. The theoretical framework below can be a reference for researchers in conducting research.

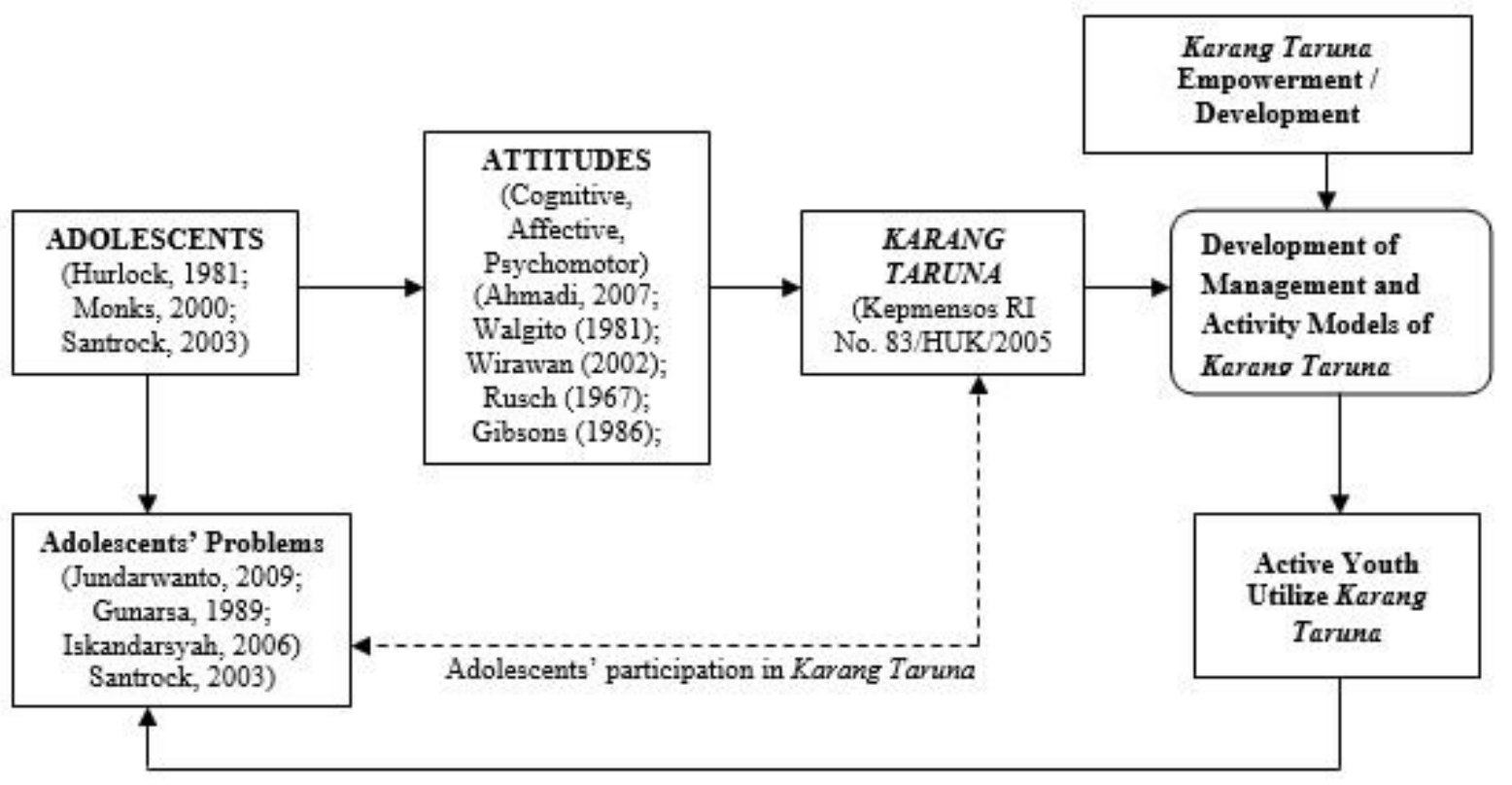

Figure 1. Theoretical Framework for Research 
Based on the background, problem formulation, and research objectives as well as theoretical frameworks which are the basis for conducting research, the research hypothesis is formulated as follows::

1. Adolescent attitudes towards Karang Taruna have a significant influence on youth involvement in Karang Taruna activities. In this case the better the attitude of adolescents towards Karang Taruna, the higher the participation of youth in Karang Taruna activities. Conversely, the worse the attitudes of adolescents towards Karang Taruna, the lower the participation of youth in Karang Taruna activities.

2. Adolescent attitudes towards Karang Taruna have a significant influence on the handling of problems faced by adolescents in their developmental life. Therefore, the better the attitude of adolescents towards Karang Taruna, the problems faced by adolescents in dealing with the development of their lives are increasingly handled. The worse the attitude of adolescents towards social organization Karang Taruna, the problems faced by adolescents are difficult in dealing with the development of their lives is difficult to handle.

3. Knowledge (cognitive), feeling (affective), tendency to behave (psychomotor); and the participation of adolescents in Karang Taruna activities, is a factor influencing the handling of problems faced by adolescents during their life development.

The various conditions and problems faced by adolescents in their developmental period encourage the importance of conducting research on adolescent attitudes towards Karang Taruna. The location of the research was conducted in Sumedang Regency, West

Java Province. The aim was to analyze the attitudes of adolescents towards the existence of of Karang Taruna in Sumedang Regency. Specifically, the purpose of this research is to gain a deep and comprehensive understanding of; (1) the characteristics of respondents in the research location; (2) problems faced by Karang Taruna; (3) the influence of adolescent attitudes about Karang Taruna to the handling of problems faced by adolescents in their development period; (4) factors of adolescent attitudes that influence the handling of problems faced by adolescents during their development through Karang Taruna; and (5) Karang Taruna activities that can meet the needs of adolescents in solving problems faced by adolescents during their life development.

The benefits of this research are expected to be useful in enriching scientific explanations in developing social work approaches to organizational development (organization development), especially the Karang Taruna through an understanding of youth attitudes towards Karang Taruna. This research is useful to enrich scientific explanations about adolescents and their problems in the developmental period of adolescent life. In addition, it is expected that the results of this study can contribute ideas and be considered for; (1) social workers in improving the organization development services of the Karang Taruna through understanding the attitudes of adolescents towards the Karang Taruna; (2) Central Government, Regional Government, NonGovernmental Organizations (NGOs), and community development practitioners in an effort to increase the effectiveness of Karang 
Taruna organizations in rural/urban villages that can accomodate the needs of adolescents in solving the problems they face.

\section{METHOD}

This research was conducted using a quantitative research approach with an explanatory survey method which is causality research by analyzing the direct and indirect effects of the factors of adolescent attitudes towards Karang Taruna towards handling adolescent problems in their life development. The quantitative method is done to test the hypothesis about "the direct influence of adolescent attitudes about Karang Taruna to the handling of problems faced by adolescents in their life development". In addition, this method is used to test the hypothesis about "the influence of adolescent attitudes about Karang Taruna to the handling of problems faced by adolescents in their life development through youth involvement in the management and activities of Karang Taruna". In accordance with the objectives and usefulness of the research to be achieved, the type of research used is the type of explanatory research. Explanative research is used because this research wants to understand and describe the causes of a social phenomenon in the handling of adolescent cases in the development of their lives through involvement in social organizations Karang Taruna.

The main hypothesis formulation contained three variables, namely the independent variable, the intervening variable, and the dependent variable. The aspects of the three variables are;

1. Independent Variable (X): Youth's Attitudes About Karang Taruna, with the following aspects; (1) adolescent knowledge about Karang Taruna; (2) adolescent feelings towards the Karang Taruna; and (3) behavioral tendencies to be involved in the Karang Taruna.

2. Intermediating Variables: Youth Involvement in Karang Taruna, with the following aspects; (1) youth involvement in the management of the Karang Taruna; (2) the involvement of adolescents in preparing the Karang Taruna activities plan; and (3) youth involvement in carrying out Karang Taruna activities.

3. Bound Variable (Y2): Handling of problems faced by adolescents in their life development, with the following aspects; (1) handling adolescent personal problems; (2) handling the influence of interpersonal relationships on adolescents; (3) handling cultural influences on adolescents; (4) handling social influences on adolescents.

The variable $X$ is thought to have a direct effect on the variables $Y 1$ and $Y 2$, and between aspects of the variable $X$, there is a relationship (correlation). Variable $\mathrm{X}$ also, is thought to influence the variable $\mathrm{Y} 2$ through the variable between Y1 (intervening variable). The relationship between these variables can be described as follows;

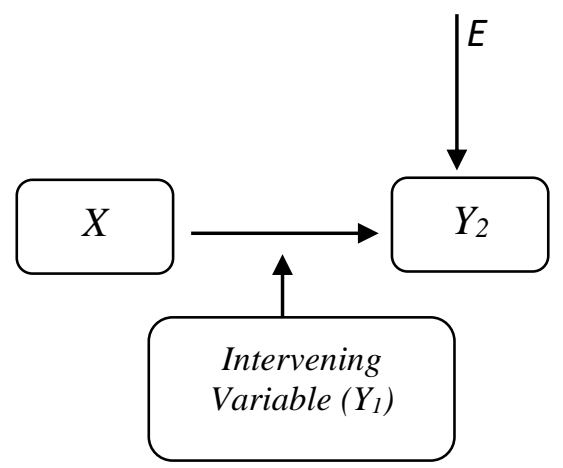

Figure 2 . Relationship between variables Description:

$E=$ Residue (influence of other variables not examined on Y2 variable) 
The level of measurement used in this research is a questionnaire constructed in the form of a Likert scale. Testing the questionnaire or measuring instruments using Pearson Product Moment Correlation analysis. Calculation of the validity of measuring instruments was carried out using Statistical Package for Social Science (SPSS) software. To find out the significance level of the coefficient is if t-count> $\mathrm{t}$-table with a $5 \%$ confidence level with a two-party test $\square=$ 0.05 and a degree of error of $(\mathrm{dk})=\mathrm{n}-2$, meaning that the measuring instrument used is valid. However, if the value of $t$-count $\leq t$ table, then the measuring instrument used is invalid.

The reliability testing of the measurement tools of this research was conducted by one shot. In this method, measurements are made only at one time then a comparison is made with other questions or by measuring the correlation between answers. In SPSS software, this method is done using the Cronbach Alpha method, where a questionnaire is said to be reliable if the Cronbach Alpha value is greater than 0.60.

Data collection techniques conducted through questionnaires and documentation study. The population in this research were adolescent residents of Sumedang Regency, both men, and women who had an age range of 12 to 21 years with classification; early teens who have an age range between 12 to less than 15 years; middle adolescent is someone who has an age between 15 years to less than 18 years, and late teens who have an age range of 18 to 21 years. The study population is spread over 26 districts in Sumedang Regency.

The sampling technique used MultiStage Cluster Random Sampling in 26 Sub- districts. From the 26 sub-districts, 7 subdistricts (25\% of the total sub-districts) were taken as the sample area. In determining the sample size of the sub-district, the draw was conducted. The determination of the research sample area based on the sub-district is based on the three regional areas of the Sumedang Regency, namely the North, Central, and South areas by division; the North part is 2 sub-districts, the middle part is 3 sub-districts and the southern part is 2 sub-districts. Therefore, there are 7 sub-districts in the sample area of research.

The target area of the sample is the village area. Therefore, from each selected sub-district area three villages $(25 \%$ of the total villages per sub-district) will be designated as a sampling area of the village area by lottery. So the total number of villages that were sampled as research was 21 villages. The population is adolescents. In this context, the problems and characteristics of adolescents are homogeneous. Therefore, this research does not require a large sample of adolescents but is based on the representation of the area of the sample. Based on this, the respondents were assigned as many as 9 adolescents for each village. Therefore, the number of adolescents who became research respondents was 189 respondents spread across 21 villages and 7 sub-districts based on 3 areas of Sumedang Regency (northern, central and southern regions). The sampling technique is done randomly.

Based on the research hypothesis, besides revealing the relationship of variables, also focused on efforts to uncover causal relationships between variables, through a transformation of ordinal data to interval data using parametric statistics using Path Analysis or Path Model. In this research, the path 
equation model used is the Two Path Equation Model. The two-path equation model consists of one independent variable (adolescent attitudes about Karang Taruna), and two dependent variables, namely; the variable of youth involvement in the management and activities of Karang Taruna and the variable handling problems faced by adolescents in their life development.

The path analysis model used in testing the variables in this research's hypothesis is a two-path equation model, which measures as many as one independent variables (X) consisting of $\mathrm{X} 1, \mathrm{X} 2$, and $\mathrm{X} 3$ against two dependent variables, namely; Y1 and Y2. Furthermore, the steps of analysis using SPSS software are adjusted to the calculation process through work procedures according to Sewal Wright (in Harun Al-Rasjid, 1993).

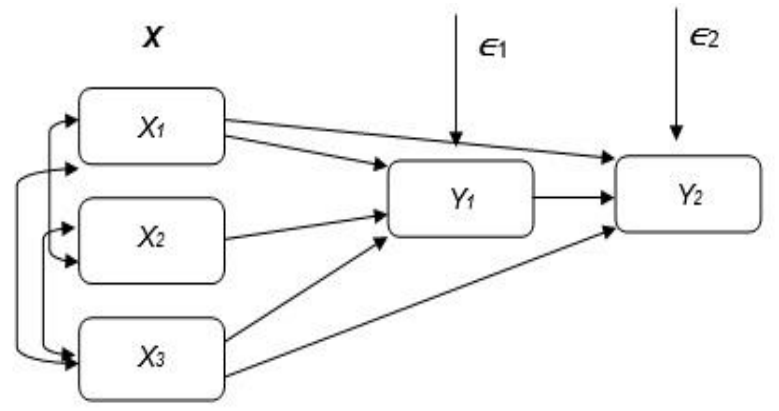

Figure 2. Path Chart Structure Model

Description:

$X_{1}=$ Adolescents knowledge about Karang Taruna;

$X_{2}=$ Adolescent feelings towards Karang Taruna;

$X_{3}=$ The desire to behave in the management and activities of Karang Taruna;

$Y_{1}=$ The involvement of adolescents in the management and activities of Karang Taruna;

$Y_{2}=$ Handling the problems faced by adolescents in their developmental life;
$E_{l}=$ Residues (other variables that affect the Y1 variable not examined in this research). $E_{2}=$ Residues (other variables that affect the Y2 variable not examined in this research).

To see the effect of $\mathrm{X}$ on $\mathrm{Y} 1$ and $\mathrm{Y} 2$, seen from the calculation results in the summary model on SPSS, especially the Rsquare numbers. The number of Rsquare numbers can be used to see how much influence $\mathrm{X}$ has on Y1 and Y2, by calculating the Coefficient of Determination (KD) using the formula: $\mathrm{KD}=\mathrm{r} 2 \times 100 \%$. The formula means that the influence of $\mathrm{X}$ on $\mathrm{Y} 1$ and $\mathrm{Y} 2$ is KD. The rest of $(100 \%$ - KD) is influenced by other factors not examined in this research ( $\square 1$ and ( $\square 2$ ). In other words, the variability of variables $\mathrm{Y} 1$ and $\mathrm{Y} 2$ that can be explained by using the variable $\mathrm{X}$, is as much as $\mathrm{KD}$. While the influence as many as (100\% - KD) caused by other variables outside this model.

\section{RESULT}

\section{The Characteristic of Respondents}

The population were adolescent residents of Sumedang Regency, both men, and women who had an age range of 12 to 21 years with classification; early teens who have an age range between 12 to less than 15 years; middle adolescent is someone who has an age between 15 years to less than 18 years, and late teens who have an age range of 18 to 21 years. The population is spread over 26 Sub-districts in Sumedang Regency.

Respondents in this research were 189 respondents spread in 21 villages and 7 sub-districts based on 3 areas in Sumedang Regency (northern, central and southern regions). Overview Characteristics of research respondents can be described below. 
a. Characteristics of Respondents by Gender

An illustration of the characteristics of respondents by gender can be seen in Figure 3 below

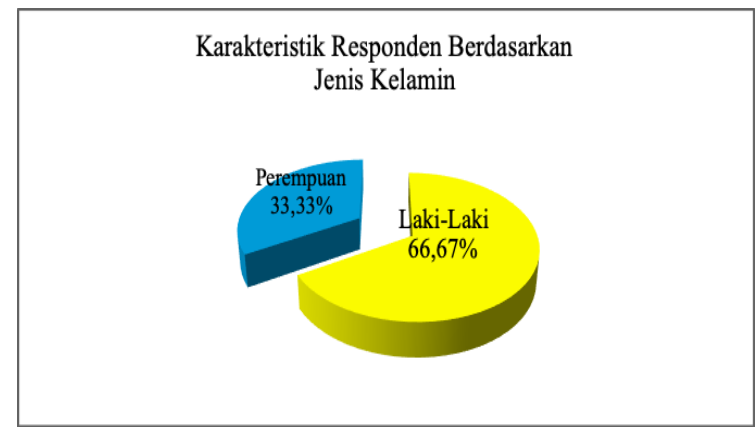

Figure 3. Characteristics of Respondents by Gender

Source: Research Results, 2019

Figure 3 shows that out of 189 respondents $66.67 \%$ were male, and the rest $(33.33 \%)$ were female. The number of male and female respondents is not the same because in the random selection of respondents for each village that has been designated as a sample area.

\section{b. Characteristics of Respondents by Age}

The characteristics of respondents by age can be seen in Figure 4 below.

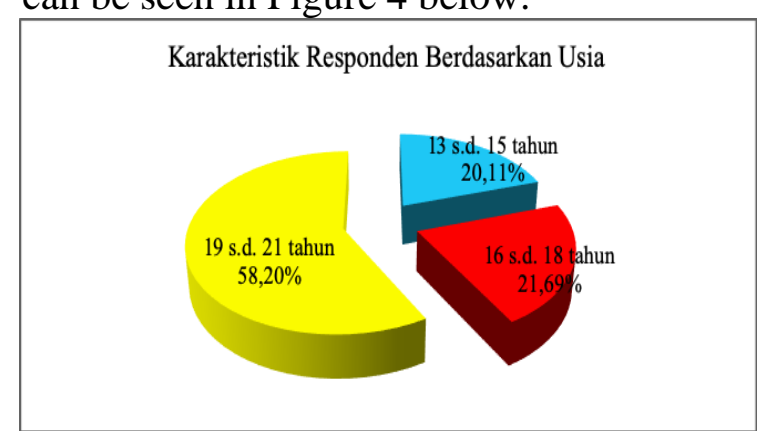

Figure 4. Characteristics of Respondents by Age

Source: Research Result, 2019

Figure 4 shows that the majority of the respondents' age was at the age interval of 19 to 21 years, amounting to $58.20 \%$ of the total respondents. On the other hand, there are $21.69 \%$ of respondents aged 16 to 18 years. The rest, as many as $20.11 \%$ aged between 13 to 15 years.

The description of the characteristics of the respondents showed that the respondents represented from each classification of adolescents according to age, namely early adolescents (ages 13-15 years), middle adolescents (aged 16-18 years), and late adolescents (aged 19-21 years). Although the numbers in each of the adolescent classifications are not the same, the above description has shown that the respondents have represented each adolescent classification. Hopefully, the data obtained can describe the conditions faced by adolescents so that the data in this study become valid

\section{c. Characteristics of Respondents by}

\section{Education Level}

The education level of the respondents in this research is the level of education at the time the research was conducted respondents had and are currently attending education. If at the time the data collection was done and the respondent was not attending education (not schooling) then the level of education of the respondent in this research was the last education that had been carried out. However, if the respondent is currently attending education, the respondent's education level is the education level at the time the respondent is at school.

An overview of the characteristics of respondents based on their level of education can be seen in Figure 5 below. 


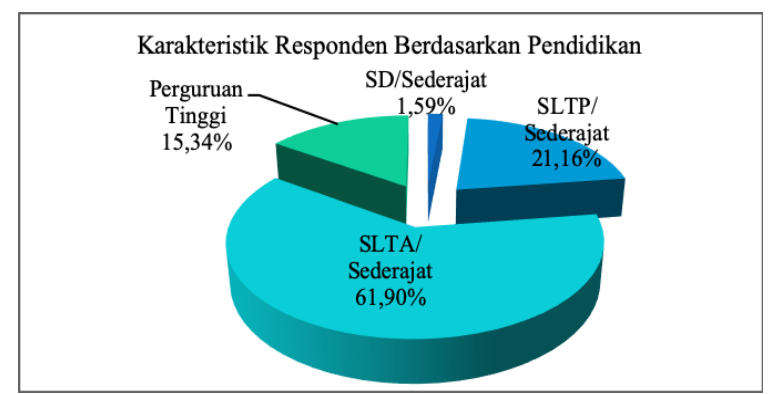

Figure 5. Characteristics of Respondents by Education Level

Source: Research Result, 2019

Figure 5 shows that the majority of respondents have a high school education level/equivalent (61.90\%), followed by a junior high school / equivalent level of $21.16 \%$, and Higher Education as much as $15.34 \%$. However, there are as many as $1.59 \%$ who have elementary/equivalent education.

\section{d. Characteristics of Respondents based on} the Activeness in Karang Taruna

The characteristics of respondents based on activeness in Karang Taruna can be seen in Figure 6 below.

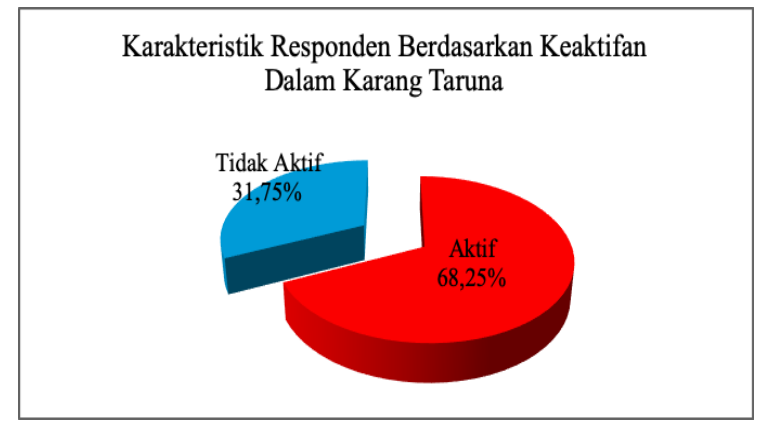

Figure 6. Characteristics of Respondents Based on Activities in Karang Taruna

Source: Research Result, 2019

Figure 6 shows that as many as $68.25 \%$ of the total respondents stated that they were active in KarangTaruna. The rest, as much as $31.75 \%$ stated not active. In this context, the respondent's activity can be seen from his participation in becoming a board member and / or participating in activities carried out by the Karang Taruna. The quantity of respondents who are active in Karang Taruna activities is a minimum of following the activities organized by Karang Taruna in their village at least once a year.

Karang Taruna members consist of passive members and active members. Passive Membership is a passive membership system (automatic membership), that is, all teenagers and young people aged 11 to 45 years. While active members are cadre members, aged 11 to 45 years and are always actively participating in Karang Taruna activities.

\section{e. Characteristics of Respondents Based on Status in Karang Taruna}

The characteristics of respondents based on the status of respondents in Karang Taruna can be seen in Figure 7 below.

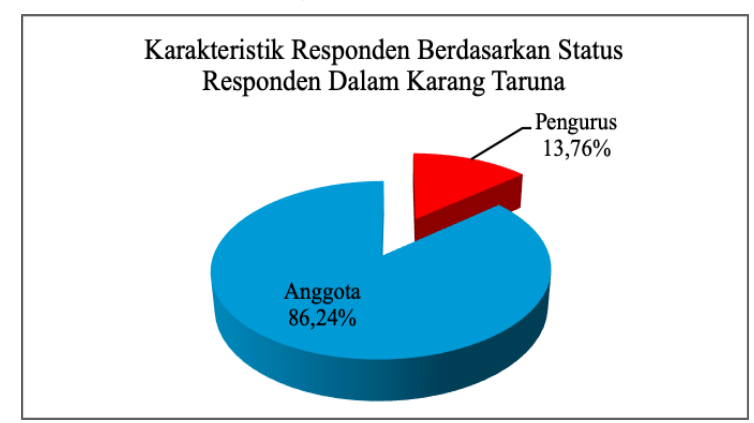

Figure 7. Characteristics of Respondents

Based on Respondent Status in KarangTaruna

Source: Research Result, 2019

Figure 7 shows that most respondents have status in Karang Taruna as members (86.24\%) of the total respondents. The rest, as much as $13.76 \%$ stated as administrators. Karang Taruna members consist of passive members and active members. Passive members are memberships that are passive systems (automatic membership), i.e. all adolescents and young people aged 11 to 45 
years. While active members are cadre members, aged 11 to 45 years and are always actively participating in Karang Taruna activities.

\section{Description of Problems Faced by} Karang Taruna

Karang Taruna grows and develops from the younger generation, managed or managed by the younger generation and for the benefit of the younger generation and the community in the village or equivalent customary community. Therefore, each village or customary community can be equal in growing and developing its own Karang Taruna. The results showed that there were still various problems faced by Karang Taruna in the implementation of its activities and organizations. Various problems faced by Karang Taruna according to respondents can be seen in Figure 8 below.

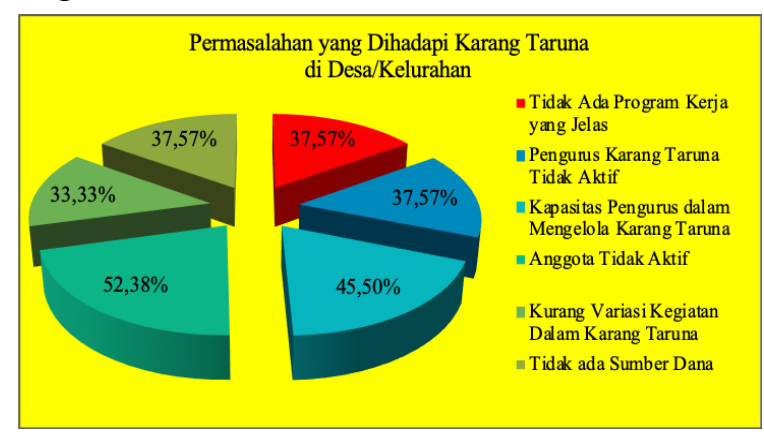

Figure 8. Overview of Problems Faced by

KarangTaruna in the Village

Source: Research Result, 2019

The results showed that there were still many problems faced by Karang Taruna in the village so that the implementation of KarangTaruna activities could not go according to the Karang Taruna objectives. Of the many problems faced by Karang Taruna, the the results of respondents' answers indicate there are six problems faced by Karang Taruna in the village. The six main problems of Karang Taruna including; (1) inactive members; (2); management capacity in managing Karang Taruna; (3) there is no clear work program; (4) Karang Taruna management is not active; (5) lack of funding sources; and (6) lack of variation in activities within Karang Taruna so that it does not appeal to its members, especially to passive members.

Respondents said that there must be various efforts to deal with the problems faced by Karang Taruna. Various efforts that must be made in dealing with various problems faced by Karang Taruna according to respondents can be seen in Figure 9 below.

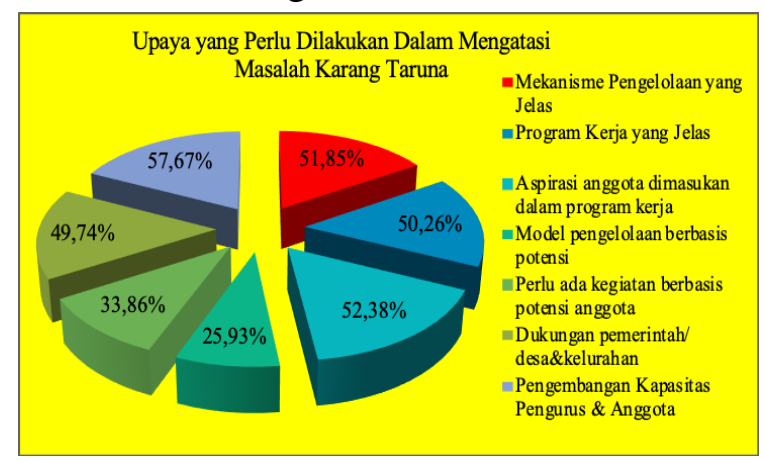

Figure 9. Efforts that Can Be Done in Overcoming the Problems Facing by Karang Taruna in the Village Source: Research Result, 2019

Figure 9 shows that there needs to be an effort that needs to be done to overcome the problems faced by Karang Taruna so that it can be used as a means in developing activities and creativity of adolescents and young people in the village. The results of respondents' answers indicate that there are seven efforts that need to be done in overcoming the problems faced by Karang Taruna in the village, namely:

a. Efforts should be made to improve and develop the capacity of management and members of Karang Taruna. The effort to 
handle the problem was chosen by $57.67 \%$ of respondents;

b. Member aspirations need to be accommodated in the Karang Taruna work program. This effort was chosen by $52.38 \%$ of respondents;

c. There is a need for a management mechanism that is clear, transparent and in accordance with the needs of members. This effort was chosen by 51.85 respondents;

d. There is a need for a clear and agreed work program by Karang Taruna members. The effort to handle the Karang Taruna problem was chosen by $50.26 \%$ of respondents;

e. Management model based on potential, both the potential of management and member HR, as well as the potential of environmental resources. This effort was chosen by $49.74 \%$ of respondents;

f. The various activities undertaken by KarangTaruna need to be adjusted to the potential of the members. In this context, the activities carried out by Karang Taruna need to be aimed at developing the potential of its members. Efforts in overcoming the problem of Karang Taruna were selected by $33.86 \%$ of respondents;

g. There needs a support from the government/village on a massive scale for the development of Karang Taruna. This effort was chosen as many as $25.93 \%$.

Karang Taruna's presence in the village as a forum for community participation, especially youth and young people in the field of social welfare should be felt by the community, especially for young people and young people. However, in its management and development, there are various problems faced by Karang Taruna so that the existence cannot be felt by adolescents and young people in villages.

Various efforts need to be made to overcome these problems so that the existence of Karang Taruna can help youth and young people in developing their creativity for selfdevelopment and improving the welfare of the community. After knowing the various problems and efforts that need to be made, the results of the study will be elaborated on the description of adolescent attitudes (cognitive, affective, and psychomotor) towards Karang Taruna.

\section{The Effect of Adolescents Attitudes} Toward Karang Taruna on Handling Problems Faced by Adolescents in their Life Development Period

In this research a hypothesis test was conducted on the independent variables of adolescent attitudes towards Karang Taruna (X) which included three aspects of variables $\mathrm{X}$ (cognitive aspects (X1); affection aspects (X2); and psychomotor aspects (X3)) on two dependent variables on adolescent participation in Karang Taruna (Y1), and handling problems faced by adolescents during their life development (Y2). Based on the hypothesis test path structure diagram, there are two hypothetical sub-structures in this research, including;

a. Sub Structure Hypothesis I: Adolescent attitudes towards Karang Taruna have a significant influence on youth involvement in Karang Taruna activities.

b. Sub Structure Hypothesis II: Adolescent attitudes towards Karang Taruna have a significant influence on the handling of problems faced by adolescents in their developmental life. 
Based on the two hypotheses above, the statistical test results about the two hypotheses can be described below.

\section{a.Statistical Test Results for Sub Structure} Hypothesis I

$\mathrm{H}_{0} \quad$ : Adolescent attitudes towards Karang Taruna have no significant effect on youth involvement in Karang Taruna activities.
$\mathrm{H}_{1}$

: Adolescent attitudes toward

Karang Taruna have a significant influence on youth involvement in Karang Taruna activities.

The results of the statistical tests carried out to test the hypothesis of sub-structure I in this research which was processed using SPSS17 can be seen below.

Model Summary

\begin{tabular}{ccccc}
\hline Model & $\mathrm{R}$ & $\mathrm{R}$ Square & $\begin{array}{c}\text { Adjusted R } \\
\text { Square }\end{array}$ & $\begin{array}{c}\text { Std. Error of } \\
\text { the Estimate }\end{array}$ \\
\hline 1 &, $783(\mathrm{a})$ &, 614 &, 608 & 5,991 \\
\hline a Predictors: (Constant), Psychomotor, Cognitive, Affection
\end{tabular}

ANOVA(b)

\begin{tabular}{ccccccc}
\hline \multirow{2}{*}{ Model } & \multicolumn{2}{c}{$\begin{array}{c}\text { Sum of } \\
\text { Squares }\end{array}$} & df & Mean Square & $F$ & Sig. \\
\hline \multirow{2}{*}{1} & Regression & 10553,195 & 3 & 3517,732 & 98,015 &, $000(\mathrm{a})$ \\
\cline { 2 - 7 } & Residual & 6639,577 & 185 & 35,890 & & \\
\cline { 2 - 7 } & Total & 17192,772 & 188 & & & \\
\hline
\end{tabular}

a Predictors: (Constant), Psychomotor, Cognitive, Affection

b Dependent Variable: Participation in Karang Taruna

Coefficients(a)

\begin{tabular}{llrrrrr}
\hline \multirow{2}{*}{ Model } & & \multicolumn{2}{c}{$\begin{array}{c}\text { Unstandardized } \\
\text { Coefficients }\end{array}$} & $\begin{array}{c}\text { Standardized } \\
\text { Coefficients }\end{array}$ & \multicolumn{1}{c}{$\mathrm{t}$} & Sig. \\
\cline { 3 - 8 } & & $\mathrm{B}$ & Std. Error & Beta & \multicolumn{1}{c}{ B } & Std. Error \\
\hline 1 & (Constant) & $-23,571$ & 7,772 & & $-3,033$ &, 003 \\
\cline { 2 - 8 } & Kognitif &, 620 &, 050 &, 621 & 12,377 &, 000 \\
\cline { 2 - 8 } & Afeksi &,- 208 &, 103 &,- 237 & $-2,025$ &, 044 \\
\cline { 2 - 8 } & Psikomotorik &, 406 &, 091 &, 517 & 4,452 &, 000 \\
\hline
\end{tabular}

a Dependent Variable: Participation in Karang Taruna

The value of $\mathrm{F}$ table is obtained with the provision of the 0.05 significance level and the Degree of Freedom (DK) with the numerator provisions: the number of variables minus 1 or $3-1=2$; and denumerator: the number of $n-$ 4 or $189-4=185$. From this provision, the number or value of $\mathrm{F}$ table is 1.96 .

The hypothesis test criteria are as follows; If the $F_{\text {research }}>F_{\text {table }}$ or if the level of significance $(\mathrm{Sig}) \quad 0.05<$ Significance of
Statistical Tests then $\mathrm{H}_{0}$ rejected and $\mathrm{H}_{1}$ accepted

If the $F_{\text {research }}<\mathrm{F}_{\text {table }}$ or if the level of significance (Sig) $0.05<$ Significance of Statistical Tests then $\mathrm{H}_{0}$ rejected and $\mathrm{H}_{1}$ accepted.

From the results of the statistical tests above, it was produced that the magnitude $F_{\text {research }}$ is 98,015. Based on this $F_{\text {research }}>F_{\text {table }}$ or 98,015 $>1,96$. Therefore, $\mathrm{H}_{0}$ is rejected and $\mathrm{H}_{1}$ is 
accepted. This means that adolescent attitudes towards Karang Taruna have a significant influence on Adolescents' involvement in Karang Taruna activities.

The magnitude of the influence of adolescent attitudes about Karang Taruna on youth involvement in Karang Taruna is as big as $\mathrm{R}_{\text {Square }} \mathrm{x} 100 \%$ or as much as $0.614 \times 100 \%=$ $61,40 \%$. The rest is equal to $1-0.614=0.386$ or as much as $38,60 \%$ influenced by other variables (residual variables) that were not examined in this research.

Correlation between variables of adolescent attitudes towards Karang Taruna (between $\mathrm{X}_{1}$ $\mathrm{X}_{2}$ and $\mathrm{X}_{3}$ variables or between aspects in variables (cognitive aspects, affective aspects, and psychomotor aspects) can be seen from the correlation obtained by the calculation of Correlations Pearson results of SPSS 17 below:

\section{Correlations}

\begin{tabular}{llrrr}
\hline & \multicolumn{1}{c}{ Kognitif } & \multicolumn{1}{c}{ Afeksi } & Psikomotorik \\
\hline Kognitif & Pearson Correlation & 1 &, $413\left(^{* *}\right)$ &, $392\left(^{* *}\right)$ \\
\hline & Sig. (2-tailed) & &, 000 &, 000 \\
\hline & $\mathrm{N}$ & 189 & 189 & 189 \\
\hline Afeksi & Pearson Correlation &, $413\left(^{* *}\right)$ & 1 &, $919\left(^{* *}\right)$ \\
\hline & Sig. (2-tailed) &, 000 & &, 000 \\
\hline Psikomotorik & $\mathrm{N}$ & 189 & 189 & 189 \\
\hline & Pearson Correlation &, $392\left(^{* *}\right)$ &, $919\left(^{* *}\right)$ & 1 \\
\hline & Sig. (2-tailed) &, 000 &, 000 & 189 \\
\hline & $\mathrm{N}$ & 189 & 189 &
\end{tabular}

Based on the above SPSS calculation results show that the correlation number between aspects in the variable can be expressed as follows:

1) The correlation between cognitive and affective aspects is 0.413 . Based on these correlation numbers, the relationship between cognitive and affective aspects in the variable of adolescent attitudes towards Karang Taruna has a fairly strong and direct correlation (because the results are positive). The unidirectional correlation has meaning if the high cognitive aspect will be followed by the higher the affective aspect. The correlation of two aspects in the variable of adolescent attitudes towards Karang Taruna is significant because the significant figure is $0,000<0.05$. This is because if the number is significant ( $\mathrm{sig}$ )
$<0.05$, then the relationship between the two aspects of the variable is significant. Conversely, if the number is significant (sig)> 0.05 then the relationship between the two aspects of the variable is not significant.

2) The correlation between cognitive aspects and psychomotor aspects is 0.392. Based on these correlation numbers, the relationship between cognitive aspects and psychomotor aspects in the variable of adolescent attitudes towards Karang Taruna has a fairly strong and direct correlation (because the results are positive). The unidirectional correlation has meaning if the cognitive aspect is high then the higher the psychomotor aspect will be followed. The correlation of two aspects in the variable of adolescent attitudes towards 
Karang Taruna is significant because the significant figure is $0,000<0.05$. This is because if the number is significant ( $\mathrm{sig}$ ) $<0.05$, then the relationship between the two aspects of the variable is significant. Conversely, if the number is significant (sig)> 0.05 then the relationship between the two aspects of the variable is not significant.

3) The correlation between affective aspects with psychomotor aspects is equal to 0.919 . Based on these correlation numbers, the relationship between affective aspects and psychomotor aspects in the variable of adolescent attitudes towards Karang Taruna has a very strong and direct correlation (because the results are positive). The unidirectional correlation has meaning if the affective aspect is high then the higher the psychomotor aspect will be followed. The correlation of two aspects in the variable of adolescent attitudes towards Karang Taruna is significant because the significant figure is $0,000<0.05$. This is because if the number is significant (sig) $<0.05$, then the relationship between the two aspects of the variable is significant. Conversely, if the number is significant (sig)> 0.05 then the relationship between the two aspects of the variable is not significant.

\section{b. Statistical Test Result for Sub-structure Hypothesis II}

$\mathrm{H}_{0}$ : Adolescent attitudes toward Karang Taruna have no significant influence on the handling of problems faced by adolescents in their developmental life.

$\mathrm{H}_{1}$ : Adolescent attitudes towards Karang Taruna have a significant influence on the handling of problems faced by adolescents in their developmental life.

The results of statistical tests carried out to test hypostesis of sub-structure II in this study which were processed using SPSS17 can be seen below.

Model Summary

\begin{tabular}{ccccc}
\hline Model & $\mathrm{R}$ & $\mathrm{R}$ Square & $\begin{array}{c}\text { Adjusted R } \\
\text { Square }\end{array}$ & $\begin{array}{c}\text { Std. Error of } \\
\text { the Estimate }\end{array}$ \\
\hline 1 &, $926(\mathrm{a})$ &, 858 &, 855 & 2,851 \\
\hline
\end{tabular}

a Predictors: (Constant), Participation in Youth, Affection, Cognitive, Psychomoto

ANOVA(b)

\begin{tabular}{lllrrrr}
\hline \multirow{2}{*}{ Model } & \multicolumn{2}{c}{$\begin{array}{c}\text { Sum of } \\
\text { Squares }\end{array}$} & df & Mean Square & \multicolumn{1}{c}{ F } & \multicolumn{1}{c}{ Sig. } \\
\hline \multirow{2}{*}{1} & Regression & 9027,700 & 4 & 2256,925 & 277,729 & ,000(a) \\
\cline { 2 - 7 } & Residual & 1495,252 & 184 & 8,126 & & \\
\cline { 2 - 7 } & Total & 10522,952 & 188 & & & \\
\hline
\end{tabular}

a Predictors: (Constant), Participation in Youth, Affection, Cognitive, Psychomotor

b Dependent Variable: Handling Adolescents' Problems

Coefficients(a)

\begin{tabular}{llrrrrrr}
\hline & & \multicolumn{2}{c}{$\begin{array}{c}\text { Unstandardized } \\
\text { Coefficients }\end{array}$} & $\begin{array}{c}\text { Standardized } \\
\text { Coefficients }\end{array}$ & t & Sig. \\
\cline { 3 - 8 } Model & & \multicolumn{2}{c}{ B } & Std. Error & Beta & B & Std. Error \\
\hline 1 & (Constant) & 6,011 & 3,789 & & 1,586 &, 114 \\
\cline { 2 - 8 } & Kognitif &, 195 &, 032 &, 250 & 6,051 &, 000 \\
\hline
\end{tabular}




\begin{tabular}{|c|c|c|c|c|c|}
\hline Afeksi & , 169 & ,049 & ,247 & 3,429 & ,001 \\
\hline Psikomotorik &,- 124 & ,046 &,- 202 & $-2,715$ & ,007 \\
\hline $\begin{array}{l}\text { Partisipasi Dalam } \\
\text { Karang Taruna }\end{array}$ & ,553 & ,035 & ,707 & 15,804 &, 000 \\
\hline
\end{tabular}

a Dependent Variable: Handling Adolescents Problems

The value $F_{\text {tabel }}$ can be with the provisions of the significance level of 0.05 and the Degree of Freedom (DK) with the provisions of the numerator: the number of variables minus 1 or $4-1=3$; and denumerator: the number $n-4$ or $189-4=185$. From this provision, a number or value is obtained $F_{\text {tabel }}$ as much as 2,60 .

The hypothesis test criteria are as follows; If the $F_{\text {research }}>F_{\text {table }}$ or if the significance level (Sig) is $0.05<$ Significance of Statistical Tests then $\mathrm{H}_{0}$ rejected and $\mathrm{H}_{1}$ accepted. If the $F_{\text {research }}<F_{\text {table }}$ or if the significance level (Sig) is $0.05<$ Significance of Statistical Tests then $\mathrm{H}_{0}$ Accepted and $\mathrm{H}_{1}$ rejected.

From the results of the statistical tests above, it was produced that the magnitude $F_{\text {research }}$ is 277,729. Based on that $F_{\text {research }}>F_{\text {table }}$ or 277,729>2,60. then $\mathrm{H}_{0}$ rejected and $\mathrm{H}_{1}$ accepted. That is, adolescent attitudes towards Karang Taruna have a significant influence on the handling of problems faced by adolescents in their developmental life.
The magnitude of the influence of adolescent attitudes about Karang Taruna on the handling of problems faced by adolescents in their development is as big as $\mathrm{R}_{\text {Square }} \mathrm{x} 100 \%$ or $0.858 \times 100 \%=85,80 \%$. The remaining $1-$ $0.858=0.142$ or $14.20 \%$ is influenced by other variables (residual variables) not examined in this research. Correlation between variables of adolescent attitudes towards Karang Taruna (between $\mathrm{X}_{1}, \mathrm{X}_{2}, \mathrm{X}_{3}$, and $\mathrm{X}_{4}$ variables) or between aspects in variables (cognitive aspects, affective aspects, psychomotor aspects, participation aspects) can be seen from the correlation obtained by the calculation of Correlations Pearson results of the following SPSS 17:

\section{Correlations}

\begin{tabular}{|c|c|c|c|c|c|}
\hline & & Cognitive & Affective & Psychomotor & $\begin{array}{l}\text { Participation in } \\
\text { Karang Taruna }\end{array}$ \\
\hline \multirow[t]{3}{*}{ Cognitive } & Pearson Correlation & 1 &, $413\left(^{* *}\right)$ &, $392\left({ }^{* \star}\right)$ &, $726\left(^{\star \star *}\right)$ \\
\hline & Sig. (2-tailed) & & ,000 & ,000 & ,000 \\
\hline & $\mathrm{N}$ & 189 & 189 & 189 & 189 \\
\hline \multirow[t]{3}{*}{ Affective } & Pearson Correlation &, $413\left({ }^{* *}\right)$ & 1 &, $919\left(^{* \star}\right)$ & ,494(**) \\
\hline & Sig. (2-tailed) &, 000 & &, 000 &, 000 \\
\hline & $\mathrm{N}$ & 189 & 189 & 189 & 189 \\
\hline \multirow[t]{3}{*}{ Psychomotor } & Pearson Correlation &, $392\left({ }^{* *}\right)$ &, $919\left(^{* *}\right)$ & 1 &, $542\left({ }^{* *}\right)$ \\
\hline & Sig. (2-tailed) &, 000 &, 000 & &, 000 \\
\hline & $\mathrm{N}$ & 189 & 189 & 189 & 189 \\
\hline \multirow[t]{2}{*}{$\begin{array}{l}\text { Participation in } \\
\text { Karang Taruna }\end{array}$} & Pearson Correlation &, $726\left(^{* \star}\right)$ &, $494\left(^{* \star}\right)$ &, $542\left({ }^{\star \star}\right)$ & 1 \\
\hline & Sig. (2-tailed) & ,000 &, 000 & ,000 & \\
\hline
\end{tabular}


** Correlation is significant at the 0.01 level (2-tailed).

Based on the above SPSS calculation results show that the correlation number between aspects in the variable can be expressed as follows:

1) The correlation between cognitive and affective aspects is 0.413 . Based on these correlation numbers, the relationship between cognitive and affective aspects in the variable of adolescent attitudes towards Karang Taruna has a fairly strong and direct correlation (because the results are positive). The unidirectional correlation has meaning if the high cognitive aspect will be followed the higher the affective aspect. The correlation of two aspects in the variable of adolescent attitudes towards Karang Taruna is significant because the significant figure is $0,000<0.05$. This is because if the number is significant ( $\mathrm{sig}$ ) $<0.05$, then the relationship between the two aspects of the variable is significant. Conversely, if the number is significant (sig)> 0.05 then the relationship between the two aspects of the variable is not significant.

2) The correlation between cognitive aspects and psychomotor aspects is 0.392. Based on these correlation numbers, the relationship between cognitive aspects and psychomotor aspects in the variable of adolescent attitudes towards Karang Taruna has a fairly strong and direct correlation (because the results are positive). The unidirectional correlation has meaning if the cognitive aspect is high then the higher the psychomotor aspect will be followed. The correlation of two aspects in the variable of adolescent attitudes towards Karang Taruna is significant because the significant figure is $0,000<0.05$. This is because if the number is significant (sig) $<0.05$, then the relationship between the two aspects of the variable is significant. Conversely, if the number is significant (sig)> 0.05 then the relationship between the two aspects of the variable is not significant.

3) The correlation between cognitive aspects and aspects of youth participation in Karang Taruna is 0.726. Based on these correlation numbers, the relationship between cognitive aspects and aspects of youth participation in Karang Taruna in the youth attitude variable towards Karang Taruna has a strong and direct correlation (because the results are positive). The unidirectional correlation has meaning, if the cognitive aspect is high then the higher aspect of adolescent participation in Karang Taruna will be followed. The correlation of two aspects in the variable of adolescent attitudes towards Karang Taruna is significant because the significant figure is $0,000<0.05$. This is because if the number is significant ( $\mathrm{sig}$ ) $<0.05$, then the relationship between the two aspects of the variable is significant. Conversely, if the number is significant (sig)> 0.05 then the relationship between the two aspects of the variable is not significant.

4) The correlation between affective aspects with psychomotor aspects is equal to 0.919 . Based on these correlation numbers, the relationship between affective aspects and psychomotor aspects in the variable of adolescent attitudes towards Karang Taruna has a very strong and direct 
correlation (because the results are positive). The unidirectional correlation has meaning if the affective aspect is high then the higher the psychomotor aspect will be followed. The correlation of two aspects in the variable of adolescent attitudes towards Karang Taruna is significant because the significant figure is $0,000<0.05$. This is because if the number is significant (sig) $<0.05$, then the relationship between the two aspects of the variable is significant. Conversely, if the number is significant (sig)> 0.05 then the relationship between the two aspects of the variable is not significant.

5) The correlation between affective aspects and aspects of youth participation in Karang Taruna is 0.494. Based on these correlation numbers, the relationship between the affective aspects and aspects of youth participation in Karang Taruna in the variable of adolescent attitudes towards Karang Taruna has a fairly strong and direct correlation (because the results are positive). The unidirectional correlation has meaning, if the affective aspect is high then the higher aspect of youth participation will be followed in Karang Taruna. The correlation of two aspects in the variable of adolescent attitudes towards Karang Taruna is significant because the significant figure is $0,000<0.05$. This is because if the number is significant ( $\mathrm{sig}$ ) $<0.05$, then the relationship between the two aspects of the variable is significant. Conversely, if the number is significant (sig)> 0.05 then the relationship between the two aspects of the variable is not significant.

6) The correlation between psychomotor aspects and aspects of youth participation in Karang Taruna is 0.542 . Based on these correlation numbers, the relationship between psychomotor aspects and aspects of youth participation in Karang Taruna in the youth attitude variable towards Karang Taruna has a strong and direct correlation (because the results are positive). The unidirectional correlation has meaning, if the psychomotor aspect is high then it will be followed by the higher aspect of youth participation in Karang Taruna. The correlation of two aspects in the variable of adolescent attitudes towards Karang Taruna is significant because the significant figure is $0,000<0.05$. This is because if the number is significant (sig) $<0.05$, then the relationship between the two aspects of the variable is significant. Conversely, if the number is significant (sig)> 0.05 then the relationship between the two aspects of the variable is not significant.

Based on the results of statistical tests on the two substructures above, it can be concluded that the attitudes of adolescents towards Karang Taruna have a significant influence on youth involvement in Karang Taruna activities. On the other hand, adolescent attitudes towards Karang Taruna have a significant influence on the handling of problems faced by adolescents in their developmental life. In this case, when adolescent attitudes towards Karang Taruna have a good category, adolescents will get involved in Karang Taruna activities. When adolescent attitudes towards Karang Taruna have a good category so that they are involved in Karang Taruna, then the problems faced by adolescents in their development can be handled

properly 
Conversely, when adolescent attitudes towards Karang Taruna have a bad category, adolescents will not participate in Karang Taruna activities. When adolescent attitudes towards Karang Taruna have a bad category, their participation in Karang Taruna is low. Therefore, when adolescents have a poor attitude towards Karang Taruna, the problems faced by adolescents in their developmental period become untreated. In effect, adolescents often find their own ways to deal with and express the handling of problems in other activities. This often results in the activities of adolescents who violate the norms, and ethics, as well as the formal laws of the community or often called juvenile delinquency. An illustration of the path diagram of the results of a statistical test can be seen in Figure 10 below.

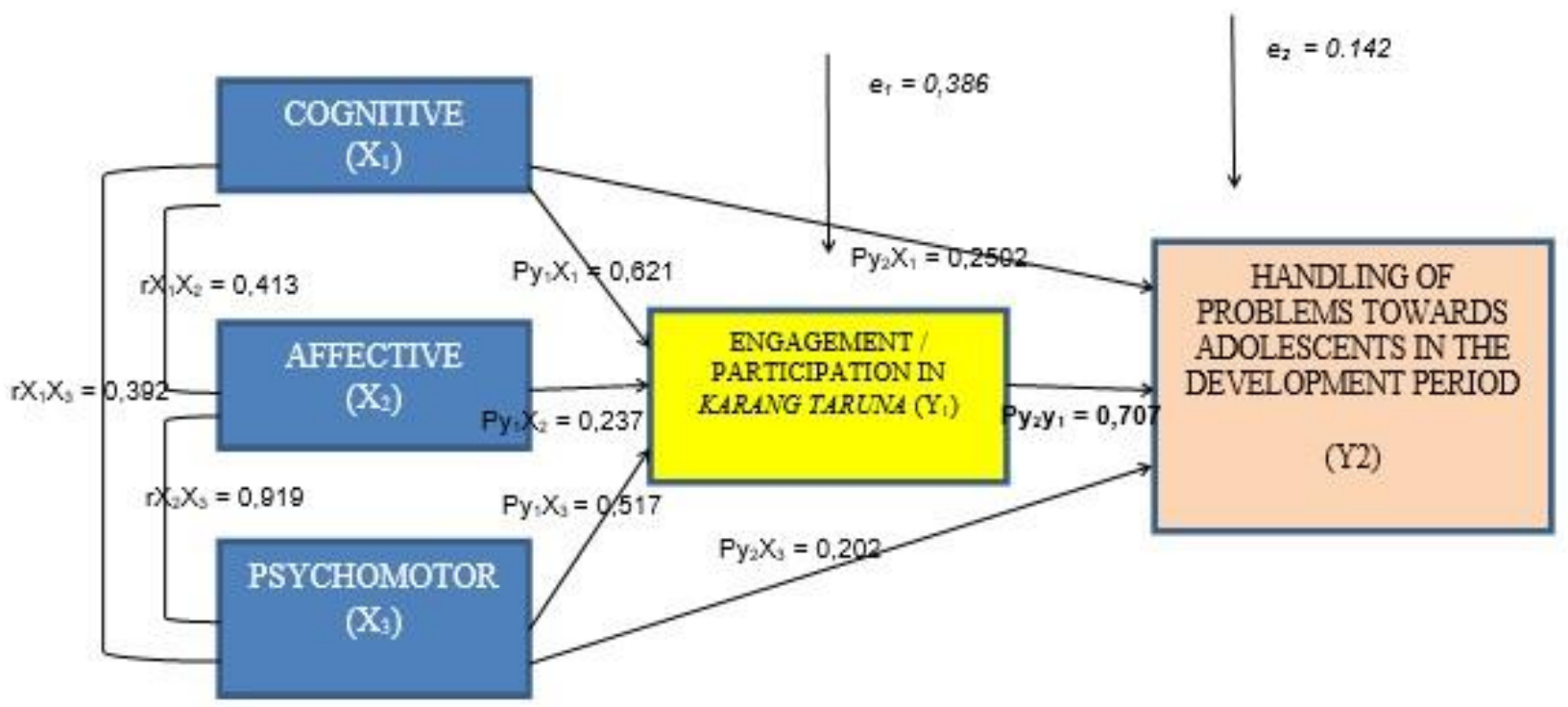

Figure 10. Diagram of Statistics Test Pathway

Figure 11 above shows the structural equation with two substructures, namely; first, $\mathrm{X}_{1}, \mathrm{X}_{2}$, and $X_{3}$, referred to as an exogenous variable and $\mathrm{Y}_{1}$ as an endogenous variable with the following substructure equation; $\mathrm{Y}_{1}=0,621 \mathrm{X}_{1}$ $-0,237 X_{2}+0,517 X_{3}+\epsilon_{1}$. Based on the results of the statistical tests on substructure I that have been carried out and described above, it can be concluded as follows:

1). The magnitude of the influence of cognitive aspects variables on the involvement/participation of adolescents in Karang Taruna is as much as 0.621 or $62.10 \%$.
2). The magnitude of the effect of the affective aspects variable on the involvement /participation of adolescents in Karang Taruna is is 0.237 or $23.70 \%$.

3 ). The magnitude of the influence of the variable psychomotor aspects on the involvement/participation of adolescents in Karang Taruna is as much as 0.517 or $51.70 \%$.

4) The magnitude of the influence of cognitive aspects, affective aspects, and psychomotor aspects together (adolescent attitudes about Karang Taruna) to the involvement/participation 
of adolescents in Karang Taruna is $\mathrm{R}_{\text {Square }}$ $\mathrm{x} 100 \%$ or as much as $0.614 \times 100 \%=$ $61,40 \%$.

5) The magnitude of the influence of other variables beyond the variables of adolescent attitudes towards KarangTaruna not examined in this research $\left(\epsilon_{1}\right)$ towards the involvement/participation of adolescents in Karang Taruna is 0.386 or $38.60 \%$.

6). The correlation between cognitive and affective aspects is 0.413 (the correlation is quite strong).

7) The correlation between cognitive and psychomotor aspects is 0.392 (the correlation is quite strong).

8) The correlation between affective aspects and psychomotor aspects is equal to 0.919 (very strong correlation).

Second, $\mathrm{X}_{1}, \mathrm{Y}_{1}$, and $\mathrm{X}_{3}$, referred to as an exogenous variable and $\mathrm{Y}_{2}$ as an endogenous variable with the following substructure equation; $\mathrm{Y}_{2}=0,250 \mathrm{X}_{1}+0,247 \mathrm{X}_{2}-0,202 \mathrm{X}_{3}$ $+0,707 Y_{1}+\epsilon_{2}$. Based on the results of the statistical tests on sub-structure II that have been carried out and described above, it can be concluded as follows:

1). The magnitude of the effect of cognitive aspects variables on the handling of problems faced by adolescents in their developmental life is as much as 0.250 or $25.00 \%$.

2). The magnitude of the effect of the variable involvement/participation of adolescents in Karang Taruna on the handling of problems faced by adolescents in their life development is as much as 0.707 or $70.70 \%$.

3). The magnitude of the influence of psychomotor aspects of variables on the handling of problems faced by adolescents in their development is as much as 0.202 or $20.20 \%$.

4). The magnitude of the influence of cognitive aspects variables, aspects of adolescent participation in Karang Taruna, and psychomotor aspects together on the handling of problems faced by adolescents in their life development is equal to RSquare $\mathrm{x} 100 \%$ or as much as $0.858 \mathrm{x}$ $100 \%=85.80 \%$.

5 ). The magnitude of the influence of other variables beyond the variables of adolescent attitudes towards Karang Taruna and participation of adolescents in Karang Taruna which were not examined in this study ( $\square 2$ ) towards the handling of problems faced by adolescents in their developmental life amounted to 0.142 or $14.20 \%$.

4. Factors of Adolescent Attitudes Toward Karang Taruna that Affect Handling of Problems Faced by Adolescents in Their Development Period Through Karang Taruna

Hypothesis test results indicate that adolescent attitudes towards Karang Taruna have a significant influence on youth involvement in Karang Taruna activities. On the other hand, adolescent attitudes towards Karang Taruna have a significant influence on the handling of problems faced by adolescents in their developmental life. Statistical test results show that cognitive aspects, affection aspects, and psychomotor aspects have a significant influence on the involvement of adolescents in Karang Taruna. Based on this, there are several factors of the variable attitudes of adolescents towards Karang Taruna which influence the level of 
participation of adolescents in Karang Taruna. These factors include:

a. The cognitive aspects or knowledge of adolescents about Karang Taruna. In this case, the cognitive aspect or knowledge and understanding of adolescents about Karang Taruna is one of the factors that can influence the level of involvement of youth in Karang Taruna. Statistical test results indicate that magnitude of the influence of cognitive aspects or knowledge of adolescents about Karang Taruna towards adolescent involvement in Karang Taruna is equal to beta $(0.621)$ $\mathrm{x} 100 \%$ is $62.10 \%$.

b. The aspects of affection or feelings of adolescents about the existence of Karang Taruna. In this case, in addition to cognitive factors, aspects of adolescent affection or feelings about the existence of Karang Taruna is also one of the factors that can influence the level of involvement of adolescents in Karang Taruna. Statistical test results show that the influence of aspects of affection or feelings of adolescents about the existence of Karang Taruna on the involvement of youth in Karang Taruna is beta $(0.237) \times 100 \%$ is $23.70 \%$

c. Psychomotor aspects or tendency to behave from adolescents to the existence of Karang Taruna. In this case, in addition to cognitive and affection factors, psychomotor aspects or a tendency to behave from adolescents to the existence of Karang Taruna is also one of the factors that can influence the level of involvement of youth in Karang Taruna. The results of statistical tests indicate that the magnitude of the influence of psychomotor aspects or the tendency to behave from calm teenagers the existence of Karang Taruna towards the involvement of adolescents in Karang Taruna is equal to beta $(0.517)$ $\mathrm{x} 100 \%$ is $51.70 \%$.

Based on the description of various factors of attitude variables that influence the involvement/participation of adolescents in Karang Taruna, it can be seen that the cognitive, affective, and psychomotor aspects of youth about Karang Taruna become a factor that can influence the level of participation/involvement of youth in Karang Taruna. Based on the results of statistical tests, cognitive factors or understanding and knowledge of adolescents about Karang Taruna is one of the factors that has the highest influence on adolescent involvement in Karang Taruna at $62.10 \%$, followed by psychomotor factors or a tendency to behave in Karang Taruna (51, $70 \%$ ), and adolescent affection factors or feelings about the existence of Karang Taruna (23.70\%).

The results of statistical tests also show that cognitive aspects, aspects of affection, psychomotor aspects, and adolescent participation in Karang Taruna have a significant influence on the handling of problems faced by adolescents during their life development. Based on this, there are several factors that influence the handling of problems faced by adolescents during their life development. These factors include:

a. The cognitive aspects or knowledge of adolescents about Karang Taruna. In this case, the cognitive aspect or knowledge and understanding of adolescents about 
KarangTaruna is one of the factors that can influence the handling of problems faced by adolescents during their development. The results of statistical tests indicate that the magnitude of the influence of cognitive aspects or knowledge of adolescents about Karang Taruna on the handling of problems faced by adolescents during their development is equal to beta $(0,250) \times 100 \%$ is $25.00 \%$.

b. The aspects of affection or feelings of adolescents about the existence of Karang Taruna. In this case, in addition to cognitive factors, aspects of adolescent affection or feelings about the existence of Karang Taruna is also one of the factors that can affect the handling of problems faced by adolescents during their development. Statistical test results show that the influence of aspects of affection or feelings of adolescents about the existence of Karang Taruna on the handling of problems faced by adolescents during their development is equal to beta $(0.247) \times 100 \%$ is $24.70 \%$.

c. Psychomotor aspects or tendency to behave from adolescents to the existence of Karang Taruna. In this case, in addition to cognitive and affective factors, psychomotor aspects or a tendency to behave from adolescents to the existence of Karang Taruna is also one of the factors that can influence the handling of problems faced by adolescents during their development. Statistical test results show that the magnitude of the influence of psychomotor aspects or the tendency to behave from calm adolescents the existence of Karang Taruna towards handling problems faced by adolescents during their development is equal to beta (0.202) x $100 \%$ is equal to $20.20 \%$.

d. Aspects of adolescents' participation in Karang Taruna. In this case, besides cognitive, affection, and psychomotor factors towards the existence of Karang Taruna, adolescents' participation in Karang Taruna is also one of the factors that can influence the handling of problems faced by adolescents during their development. The results of statistical tests show that the magnitude of the influence of aspects of adolescent participation in Karang Taruna on the handling of problems faced by adolescents during their development is beta $(0.707) \times 100 \%$ is $70.70 \%$.

Based on the description of various factors that influence the handling of problems faced by adolescents in their developmental period, it can be seen that the cognitive, affective, psychomotor aspects of adolescents about Karang Taruna and adolescent participation in Karang Taruna are factors that can influence the handling of problems faced by adolescents during their lifetime. The development of their life Based on the results of statistical tests, adolescent participation factor in Karang Taruna is one of the factors that has the highest influence on the handling of problems faced by adolescents during their development, which is $70.70 \%$, followed by cognitive factors or knowledge and understanding of Karang Taruna $(25.00 \%$ ), adolescent affection factors or feelings about the existence of Karang Taruna (24.70\%), and psychomotor factors or the tendency to behave in Karang Taruna (20.20\%). 
5. Karang Taruna Activities that Can Meet the Needs of Adolescents in Resolving Problems Faced by Adolescents during their Life Development Period

The results of statistical tests on the research hypothesis show that adolescent attitudes towards Karang Taruna have a significant influence on the handling of problems faced by adolescents during their life development. Adolescent attitudes which include cognitive, affective, and psychomotor aspects affect adolescent participation. On the other hand, adolescent attitudes toward Karang Taruna and youth participation in Karang Taruna have a significant influence on the handling of problems faced by adolescents during their life development.

However, the results of the research indicated that there are various expectations related to Karang Taruna which are needed by adolescents in solving problems faced during their life development. These expectations can be described below.

\section{a. Adolescents Hope Against Karang Taruna Management}

The results of research on adolescent expectations towards the management of
Karang Taruna can be seen in Figure 11 below.

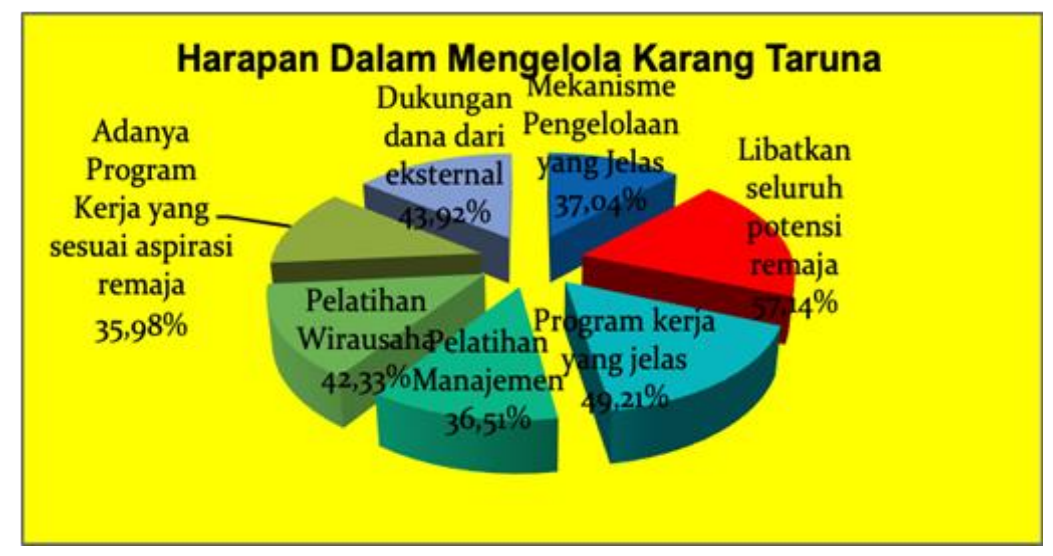

Figure 11. Adolescents Hope for KarangTaruna Management Source: Research Result, 2019

Figure 11 shows that out of 189 respondents $57,14 \%$ expect that all potential youth in the village are involved in the management of Karang Taruna. As many as $49.21 \%$ of the total respondents expected that there would be a clear work program from the Karang Taruna management. In addition to the two expectations above, there are various expectations from adolescents in the management of Karang Taruna, including:
1) There is a need for management training (management) of Karang Taruna

2) There is a need for entrepreneurship training for managers and members of Karang Taruna.

3) There is a need for financial support to fund various activities and programs from external parties as a stimulant for activity costs in Karang Taruna.

4) Need to accommodate the aspirations of adolescents in the Karang Taruna program. 
5) There needs to be a clear and approved and understood by all Karang transparent management mechanism Taruna members.

for Youth Organization that is

\section{b. Adolescents Hope Against Karang Taruna Management}

The results of research on adolescent

Karang Taruna can be seen in Figure 12 expectations towards the management of below.

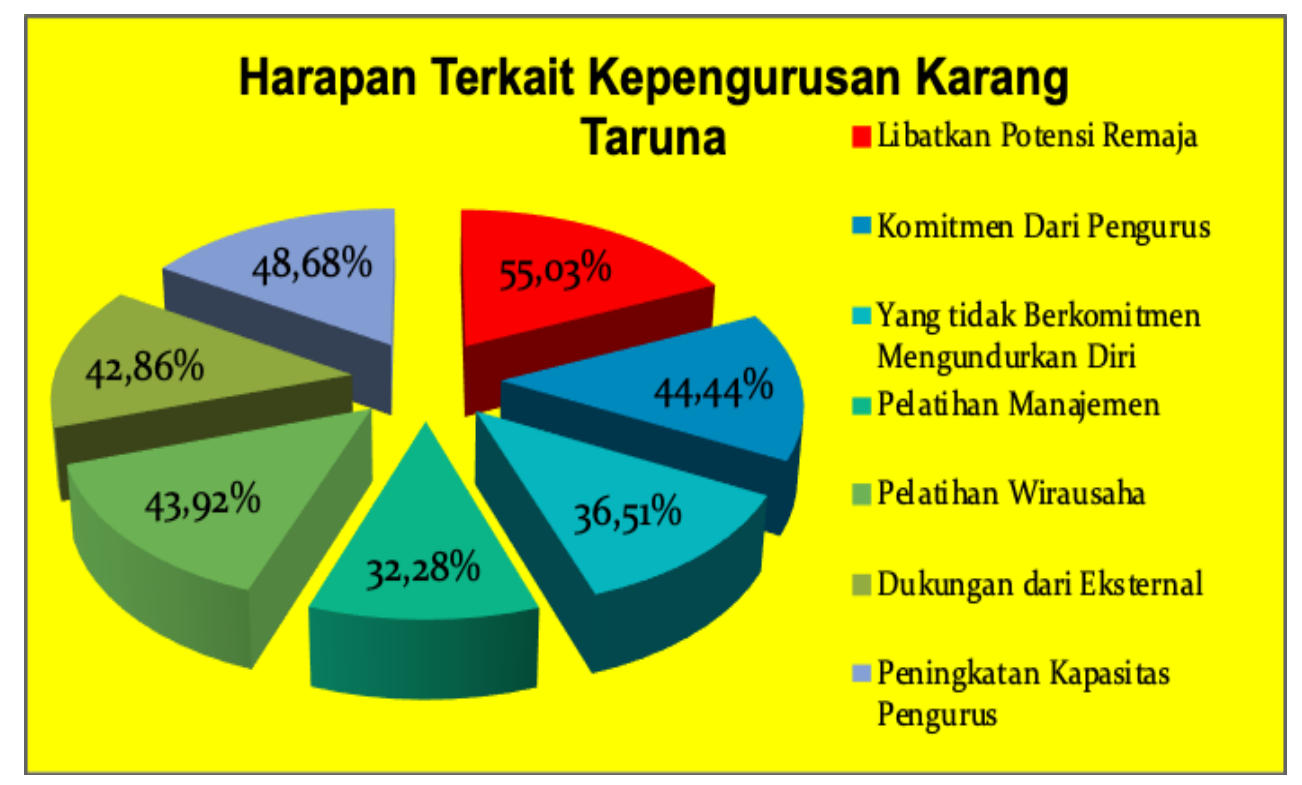

Figure 12. Adolescents Hope for Karang Taruna Management Source: Research Result, 2019

Figure 12 shows that out of 189 respondents $55.03 \%$ expect that the entire potential of adolescents in the Village will be involved in the management of KarangTaruna. As many as $48.68 \%$ of the total respondents expect that there needs to be an increase in capacity for the Karang Taruna management through Karang Taruna management training. In addition, there were $44.44 \%$ of respondents stated that there was a need for commitment from the management to manage Karang Taruna. In addition to the three expectations above, there are various expectations of adolescents in the management of Karang Taruna, namely:
1) Those who do not have the commitment to take care of Karang Taruna are expected to resign

2) Karang Taruna management training is needed for the management and members.

3) Entrepreneur training is needed for the management and members of Karang Taruna.

4) There needs to be support from the government and village heads in the form of financial assistance for the development of the Karang Taruna business.

5) Efforts should be made to develop the capacity of the management and members in managing Karang Taruna. 


\section{c. Youth Hope for Youth Membership}

The results of research on the expectations of adolescents towards youth membership can be seen in Figure 13 below.

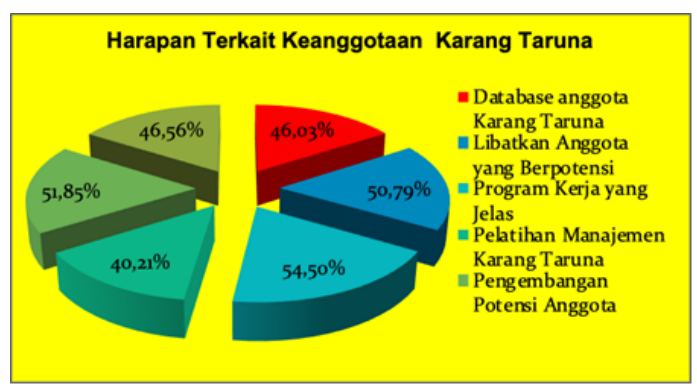

Figure 13. Adolescents Hopes of Karang Taruna Membership Source: Research Result, 2019

Figure 13 shows that as many as $54.50 \%$ of the respondents expected that there would be a clear work program for the removal of potential Karang Taruna members. As many as $51.85 \%$ expect that there is management training for Karang Taruna management and members, and as much as $50.79 \%$ of respondents expect to involve all potential youth in the management of Karang Taruna. In addition to the three expectations above, there are various expectations from adolescents in the Karang Taruna membership, namely:

1) There is a need for a database or a list of members who have good potential in sports, arts and business development.

2) It is necessary to develop the potential of the members in the fields of sports, arts and productive economic endeavors.

3) There needs to be support from the government and village heads in the form of financial assistance for the development of the Karang Taruna business.

\section{d. Youth Hope Against Karang Taruna Activities}

The results of research on adolescent expectations of Karang Taruna activities can be seen in Figure 14 below.

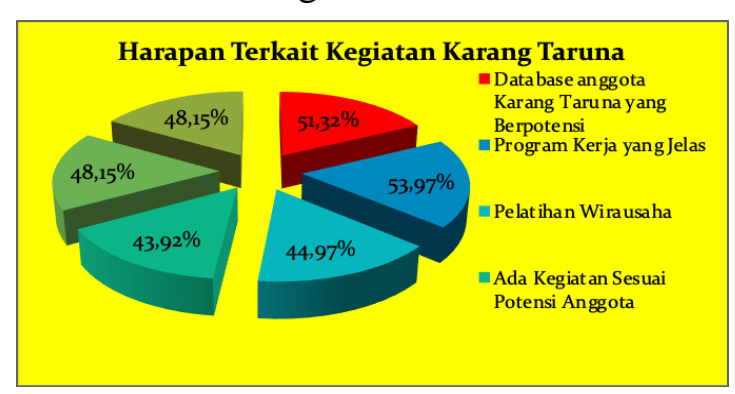

Figure 14. Youth's Hopes of Karang

Taruna Activities

Source: Research Result, 2019

Figure 14 shows that as many as $53.97 \%$ of the respondents expect that there is a clear work program in Karang Taruna activities. As many as $51.32 \%$ of respondents expect that there is a need for a database or a list of members who have good potential in the fields of sports, arts and business development. In addition to the two expectations above, there are various expectations from adolescents towards the activities carried out by Karang Taruna, namely:

1). It is necessary to develop the potential of the members in the fields of sports, arts and productive economic business.

2). Activities are needed that can accommodate the development potential of its members.

3). There needs to be support from the government and village heads in the form of financial assistance for the 
development of the Karang Taruna business

4). Efforts should be made to develop the capacity of the management and

\section{DISCUSSION}

Adolescence is the most important development period for individuals is, in fact, a period that is loaded with change and is prone to problems. Adolescence is a period of identity crisis or the search for self-identity.

Every period of human life has its own problems, including the adolescents period. Adolescents in general experience that the search for identity or integrity is a major problem because of social, physiological and psychological changes in themselves and in the communities where they live. This change is coupled with exposure to changes in social and moral degradation that is increasingly complex and modern technology. The low economic, social and educational status of parents will create problems for adolescents. Fulfillment of children's rights including the fulfillment of nutrition, education, and fulfillment of other children's needs is hampered.

Summarize some of the characteristics of adolescents that can cause various problems in adolescents, namely; (1) awkwardness in association and rigidity in movement; (2) emotional instability; (3) there is an empty feeling due to reshuffle of outlook and life direction; (4) the existence of resistance and challenge to parents; (5) conflicts within themselves often become the root cause of conflicts with parents; (6) anxiety because many things are desirable but adolescents are unable to fulfill all of them; (7) happy to experiment; (8) enjoy exploring; (9) has many fantasies, delusions, and boasting; and (10) members in managing Karang Taruna.

tendencies to form groups and tendencies to group activities.

The period of adolescence requires a teenager to abandon his childish qualities and must learn new patterns of behavior and attitudes to replace and abandon previous patterns of behavior. During the transition in this period, often a teenager feels confused and unclear about the role demanded by the environment. For example, when individuals display children's behavior they will be asked to behave according to their age, but in contrast, if individuals try to behave like adults it is often said that they behave too mature for their age. When adolescents can not adjust to the period of their life development, then often adolescents fall into behavior that is contrary to ethics and community habits or so-called juvenile delinquency.

Nowadays, juvenile delinquency is increasingly prevalent with various forms of deviant behavior. Juvenile delinquency at this time is not only in the form of skipping school, stealing petty at the store, disobedient to parents, etc., but it leads to acts of crime, such as mass fights (brawls) that cause death, rape, murder, etc. -Other. The results of the study also showed that premarital sex and the presence of adolescents under the age of 18 giving birth or giving birth, abortion due to adolescents who are not yet pregnant is a problem facing adolescents today. Meanwhile, cases of nutritional disorders in adolescents. Sexually transmitted infections (STIs) and drug abuse are increasingly common in 
adolescents. The results revealed that the problems faced by adolescents need to be anticipated so that they do not become obstacles in their development.

Referring to the opinion of Jundarwanto (2009), there are 10 major problems faced by adolescents in Sumedang Regency, namely; (1) student brawls and fights; (2) violence against children in school; (3) pornography that threatens children and adolescents; (4) Narcotics problems in children and adolescents; (5) increasing cases of HIV / AIDS among the younger generation; (6) teenage promiscuity; (7) street children; (8) malnutrition in children; (9) the low International Student Education Index Value for Indonesian students; and (10) the problem of ethical and moral degradation of teenagers.

Referring to the problem of adolescents, the presence of Karang Taruna in the village as a forum for community participation, especially young people and young people in the field of social welfare should be felt by the community, especially for young people and young people. In this context, the Karang Taruna was formed as an effort to minimize juvenile delinquency. Karang Taruna was formed as a solution for adolescents and young people to develop their abilities in efforts to meet the needs of adolescents.

The involvement of adolescents in Karang Taruna activities has a significant correlation with the attitudes of adolescents towards the Karang Taruna. In this case, adolescent attitudes towards the Karang Taruna will have a direct impact on the level of involvement of adolescents in the implementation of Karang Taruna activities. If adolescent attitudes towards Karang Taruna are low or poor, it will be followed by a low level of participation in Karang Taruna activities. Conversely, if the attitude of adolescents towards Karang Taruna is high or good, it will be followed by a high level of youth participation in its activities.

The results showed that adolescent attitudes towards Karang Taruna had a significant influence on youth involvement in its activities. The magnitude of the influence of adolescent attitudes about KarangTaruna towards adolescents' involvement is $61.40 \%$. The remaining $38.60 \%$ is influenced by other variables (residual variables) not examined in this research. Aspects of adolescent attitudes that affect adolescent involvement in Karang Taruna include; (1) adolescent knowledge about KarangTaruna; (2) adolescent feelings towards the Karang Taruna; and (3) behavioral tendencies to be involved in the Youth Organization. On the other hand, various aspects of youth involvement which are influenced by adolescent attitudes towards Karang Taruna include; (1) youth involvement in the management of the Karang Taruna; (2) the involvement of adolescents in preparing the activities plan; and (3) adolescents involvement in carrying out Karang Taruna activities. The results showed that the cognitive aspects (knowledge) of adolescents about Karang Taruna had the greatest influence on the involvement of adolescents in Karang Taruna followed by psychomotor aspects, and the affective aspects of adolescents towards Karang Taruna.

The adolescent attitude toward Karang Taruna is a process that makes an adolescent choose, organize and interpret the stimuli received about Karang Taruna into a meaningful and complete picture of the organization. Adolescent attitudes towards Karang Taruna arise because of stimuli from outside which will affect an adolescent 
through the five senses. The stimulus will be selected, organized and interpreted by each adolescent in their own way. Based on this, it can be seen that adolescent attitudes towards Karang Taruna can arise due to external stimuli that will suppress a person's sensory nerves and through the five senses, namely, vision, hearing, smell, feeling and touch, then the stimuli will be selected.

The process of forming adolescent attitudes towards Karang Taruna as the meaning of the observations of adolescents begins with a stimulus about the Karang Taruna. After getting a stimulus, the next step is a selection that interacts with interpretation. The selection process occurs when an adolescent obtains information about Karang Taruna and its activities, the process of selecting messages about which messages are considered important and not important will take place. The selection process will be arranged into a unified sequence and meaningful, while the interpretation takes place when the person concerned gives an interpretation or meaning to the information as a whole. Based on the process of forming these attitudes, it can be concluded about the highs and lows and goods of adolescent attitudes towards the Karang Taruna.

The interpretation phase in the formation of attitudes, past or past experiences plays an important role. Functional factors that determine a person's attitude come from needs, past experience and other things including those referred to as personal factors. Based on this, there are two factors that can determine the level of adolescent attitudes about the Karang Taruna, namely; factors of past experience and personal factors of adolescents.

Factors of adolescent past experience about the Karang Taruna which influence adolescent attitudes about it, include; (1) Karang Taruna in accommodating various needs in supporting youth development; (2) the past experiences of adolescents about whether or not the aspirations of adolescents are accommodated in developing their activities and creativity in the Karang Taruna; and (3) adolescent past experiences of the high and low cohesiveness of the Karang Taruna management.

As for personal factors of adolescents that affect adolescent perceptions about Karang Taruna, covering; (1) the level of understanding and knowledge of adolescents about the Karang Taruna; (2) the level of support felt by adolescents from stakeholders, especially government officials, community leaders, and Karang Taruna partner organizations towards youth activities in Karang Taruna; (3) whether or not young people are interested in Karang Taruna activities; and (4) the level of youth awareness about the goals and benefits of Karang Taruna.

Based on this, the good or bad attitude of adolescents towards Karang Taruna will affect the high or low involvement of adolescents in Karang Taruna. The involvement of adolescents in the activities is implemented in terms of; (1) youth involvement in the management of the Karang Taruna organization; (2) the involvement of adolescents in preparing the Karang Taruna activities plan; and (3) youth involvement in carrying out the activities.

Participation is a term that is always associated with the development and handling of social problems. The term participation is synonymous with participation, both physical and non-physical involvement of an individual or community. Referring to the opinion of 
Holil Soelaiman (1980) that the notion of adolescent social participation refers to the active involvement of adolescents individually, groups in community unity in the process of joint decision making, program planning, and implementation as well as service efforts and social welfare development within and outside the community. on the basis of their sense and awareness of social responsibility.

The above description illustrates that the social participation of adolescents in Karang Taruna means that adolescents are the subject of development, so participation has a dual meaning, namely as a means of carrying out development programs and as a goal of development itself. Therefore activities that can be categorized as participation in Karang Taruna namely:

1. Participate in making preparations for the implementation of programs in Karang Taruna.

2. Participate in deliberation in program planning to find alternative programmes that are the best to be implemented in Karang Taruna.

3. Participate in implementing what has been decided in Karang Taruna.

4. Participate in overseeing the implementation of Karang Taruna program activities.

With regard to forms of youth participation in KarangTaruna, various participation that youth can give in organizations includes; (1) participation of ideas, which are given in the form of weekly meetings, the event there, meetings or meetings; (2) labor participation, namely in various activities in the form of human work for improvement and development, help for others; (3) the participation of property, which is given by people in various activities for the repair or construction of assistance for others (4) participation in skills and skills, given by people to encourage a variety of forms of business and industry; and (5) social participation such as social gathering, cooperatives and so on. From this description, it can be concluded that the main elements of the forms and types of adolescents' participation in Karang Taruna are their involvement in the stages of assessment activities, program planning, program implementation, and evaluation of problemsolving programs in Karang Taruna.

The problem of adolescents as a problematic age. Every period of human life has its own problems, including the teenage period. Teenagers are often difficult to overcome their problems. There are two reasons why this happens, namely: first; when they were children, all their problems were always overcome by adults. This is what makes teenagers do not have experience in dealing with problems. Second; because adolescents feel themselves to be independent, then they have prestige and refuse help from adults.

Adolescents in general experience that the search for identity or wholeness is a major problem because of social, physiological and psychological changes in themselves and in the community where they live. This change is intensified in our increasingly complex and modern technological society.

The results showed that adolescent attitudes towards Karang Taruna have a significant influence on the handling of problems faced by adolescents during their life development through variables between youth involvement in Karang Taruna. The results showed that adolescent attitudes towards 
Karang Taruna which include; cognitive, affective, and psychomotor aspects of adolescents about Karang Taruna have a significant influence on youth involvement/participation in Karang Taruna. As a forum for developing activities and creativity of adolescents, Karang Taruna can be provided a means in handling problems faced by adolescents during their life development. If they are involved in Karang Taruna, they can develop their potential and interests, including efforts to find out and solve the problems they face. With the involvement of adolescents, the problems faced during the development of his life can be handled optimally.

The results showed that the problems faced by adolescents during their life development that can be handled through adolescent involvement in Karang Taruna include; (1) problems of social and interpersonal relationships, including lack of warmth from parents, supervision, control, and encouragement, negative assessment from parents, tension at home, divorce and separation from parents; (2) cultural influences and manners, the use of alcohol and drugs as symbols of rejection of conventional standards, oriented towards short-term goals and hedonic satisfaction; (3) personal influences: including temperamental, aggressive personalities, people who have an external locus of control, low self-esteem, poor coping abilities; (4) love and heterosexual relationships; (5) sexual problems; (6) adolescent relations with both parents; and (7) moral, values and religious issues.

The results showed that the influence of adolescent attitudes about Karang Taruna through the involvement of adolescents in
Karang Taruna towards the handling of problems faced by adolescents in their developmental period was $85.80 \%$. The meaning shows that adolescent attitudes and adolescent involvement in Karang Taruna have an influence of $85.80 \%$ on the handling of problems faced by adolescents during their life development. The rest, amounting to $14.20 \%$ is influenced by other variables not examined in this research.

The results of this research indicate that Karang Taruna can be used as a forum for young people/adolescents in dealing with various problems in their development. Karang Taruna can be used as a means to develop the activities and creativity of adolescents in handling problems encountered during their life development. However, the results of the study show that there are still six main problems of the Karang Taruna organization in Villages. The six problems include; (1) inactive members; (2); management capacity in managing Karang Taruna; (3) there is no clear work program; (4) Karang Taruna management is not active; (5) lack of funding sources; and (6) lack of variation in activities within Karang Taruna so that it does not appeal to its members, especially to passive members.

Referring to the problems faced by Karang Taruna, there need to be various efforts to deal with the problems faced by Karang Taruna. The results showed that various efforts that must be made in dealing with various problems faced by Karang Taruna include;

1. Efforts should be made to improve and develop the capacity of management and members of Karang Taruna.

2. Member aspirations need to be accommodated in the work program. 
3. There is a need for a management mechanism that is clear, transparent and in accordance with the needs of members.

4. There is a need for a clear and approved work program by Karang Taruna members.

5. Management model based on potential, both the potential Human Resource of management and member as well as the potential of environmental resources.

6. The various activities undertaken by Karang Taruna need to be adjusted to the potential of the members. In this context, the activities carried out by Karang Taruna need to be aimed at developing the potential of its members.

7. There needs to be support from the government/village on a massive scale for the development of Karang Taruna.

The presence of Karang Taruna in the village as a forum for community participation, especially adolescents and young people in the field of social welfare should be felt by the community, especially for adolescents and young people. However, in its management and development, there are various problems faced by Karang Taruna so that the existence of Karang Taruna cannot be felt by adolescents and the young generation in the village. Various efforts need to be made to overcome these problems so that the existence of Karang Taruna can help adolescents and young people in developing their creativity for self-development and improving the welfare of the community members.

\section{CONCLUSION}

The results showed that there were six problems faced by Youth in the village. The six main problems of Karang Taruna include; (1) inactive members; (2); management capacity in managing Karang Taruna; (3) there is no clear work program; (4) Karang Taruna management is not active; (5) lack of funding sources; and (6) lack of variation in activities within Karang Taruna so that it does not appeal to its members, especially to passive members.

On the other hand, the results of the research also revealed that there were seven efforts that needed to be done in overcoming the problems faced by Karang Taruna in the village, namely;

1. Efforts should be made to improve and develop the capacity of management and members. The effort to handle this Karang Taruna problem was chosen by $57.67 \%$ of respondents;

a. Member aspirations need to be accommodated in the Karang Taruna work program.;

b.There is a need for a management mechanism that is clear, transparent and in accordance with the needs of members;

c. There is a need for a clear and agreed work program by Karang Tarunamembers;

d.Management model based on potential, both the potential Human resource of management and member, as well as the potential of environmental resources;

e. The various activities undertaken by Karang Taruna need to be adjusted to the potential of the members. In this context, the activities carried out by Karang Taruna need to be aimed at developing the potential of its members;

f. There needs to be support from the government/village on a massive scale 
for the development of Karang Taruna.

2. Adolescent attitudes towards Karang Taruna have a significant influence on youth involvement in Karang Taruna activities. The magnitude of the influence of adolescent attitudes about Karang Taruna towards youth involvement in Karang Taruna is $61.40 \%$. The remaining $38.60 \%$ is influenced by other variables (residual variables) that were not examined in this research.

3. Adolescent attitudes towards Karang Taruna have a significant influence on the handling of problems faced by adolescents in their developmental life. The magnitude of the influence of adolescent attitudes about Karang Taruna on the handling of problems faced by adolescents in their development is $85.80 \%$. The remaining $14.20 \%$ is influenced by other variables (residual variables) not examined in this research.

Karang Taruna can be used as a tool in handling problems faced by adolescents in their life development. The involvement of adolescents in Karang Taruna has the most influence on the handling of problems faced by adolescents during their life development $(70.70 \%)$. Therefore, it is recommended need efforts to increase the involvement/participation of adolescents in the management and activities of Karang Taruna through increased knowledge, psychomotor, and adolescent affection about Karang Taruna

Adolescent attitudes towards Karang Taruna have a significant influence on youth involvement in the management and activities of Karang Taruna $(61.40 \%)$. The aspects of adolescent attitudes about Karang Taruna that most influence youth involvement in Karang
Taruna are Cognitive aspects (62.10\%; followed by Psychomotor Factors $(51.70 \%)$

Therefore, to increase adolescent involvement in Karang Taruna, cognitive aspects need to be improved and youth psychomotor about Karang Taruna through socialization activities and increasing youth motivation.

Karang Taruna can be used as a tool in handling problems faced by adolescents in their life development. The attitude and involvement of adolescents in Karang Taruna has an influence on the handling of problems faced by adolescents during their life development. Therefore, it is recommended:

1. There needs to be a grand design of various activities within Karang Taruna that can meet the needs of adolescents in handling problems faced during their life development.

2. There is a need to develop a management model and Karang Taruna activities that can meet the needs of adolescents so that youth participate in Karang Taruna activities.

\section{REFERENCES}

A. Siporin Max. (1975). Introduction to Social Work Practice. Macmillan Publishers, New York.

Asngari (1984). Psikologi Sosial. Bandung Remaja Rosdakarya

Atkinson \& Hilgard's (1991). Introduction to Psychology (14 th ed)., London: Harcourt College Publishers,

Fagan, R. (2006). Counseling and Treating Adolescents with Alcohol and Other Substance Use Problems and their Family. The Family Journal: Counseling therapy For Couples and Families. Vol.14. No.4.326-333. Sage Publication diakses melalui

http://tfj.sagepub.com/cgi/reprint/14/4/326 pada 18 April 2008 
Gibson, James (1986). Organisasi Prilaku, Struktur dan Proses. Diterjemah oleh Djoerban Wahid. Erlangga. Jakarta

Gunarsa, S. D. (1989). Psikologi perkembangan: Anak dan Remaja. Jakarta: BPK. Gunung Mulia.

Hurlock, E.B. (1991). Psikolgi Perkembangan Suatu Pendekatan Sepanjang Rentang Kehidupan (Terjemahan oleh Istiwidayanti dan Soedjarwo). Jakarta : Penerbit Erlangga.

Iskandar, Jusman (1999). Metode Penelitian. Universitas Garut. Garut

Iskandarsyah. Aulia (2006). Remaja dan Permasalahannya: Perspektif psikologi terhadap permasalahan remaja dalam bidang pendidikan. Bandung : Universitas Padjadjaran

Jundarwanto (2009). Masalah Generasi Muda. http://korananakindonesia. wordpress.com

Keputusan Menteri Sosial RI Nomor: 83/PEGHUK/2005 Tentang Pedoman Karang Taruna. Jakarta: Kementrian Sosial RI.

Moh. Nazir (1998). Metode Penelitian. Jakarta. Ghalia Indonesia.

Mongks, F. J., Knoers, A. M. P. , \&

Haditono, S. R. (2000). Psikologi Perkembangan: Pengantar dalam berbagai bagiannya. Yogyakarta: Gadjah Mada University Press.

Pincus Allan, Anne Minahan (1973). Social Work Practice; Model and Method. F.E. Peacock Publishers, Inc.,Hasco. Illeanis.

Purbayu Budi Santosa dan Ashari (2005) Analisis Statistik dengan Microsoft Excel \& SPSS. Penerbit Andi. Yogyakarta.

Putranti. Nurita (2009). Remaja dan Permasalahannya. http://www.psbpsma.org/content/blog/remaja-danpermasalahannya-part-1

Rakhmat. Jalaluddin (1998). Psikologi Komunikasi. Bandung: Remaja Rosdakarya

Rajasa, Hata (2007). Membangun Karakter dan Kepribadian Bangsa.http://www.setneg.go.id/index.php? option $=$ com_content $\&$ task $=$ view $\&$ id $=529 \&$ Itemid $=116$
Rey Lachièze and M Mbelek J.-P. (2002), International Journal of Modern Physics A, vol.17, 29, p.4317-4323 (november 2002) ..

Ruch, F.L., \& Ruch, W.M. (1967). The K factor as a (validity) suppressor variable in predicting success in selling. Journal of Applied Psychology, 51, 201-204.

Santrok, J. W. (2003). Adolescence (Perkembangan Remaja). Terjemahan. Jakarta: Penerbit Erlangga.

Setiono, L.H. (2002). Beberapa Permasalahan Remaja. Diakses dari www.e-psikologi.com pada tanggal 22 April 2006.

Singarimbun, Masri dan Sofyan Effendi (1989) Metode Penelitian Survei. LP3ES. Jakarta

Soehartono,Irawan (1995). Metode Penelitian Sosial Bandung. PT Remaja Rosda Karya

Soetarso (1992). Praktek Pekerjaan Sosial. Bandung. Kopma STKS

----------. 1993. Kesejahteraan Sosial, Pelayanan Sosial, dan Kebijakan Sosial. Bandung: STKS

Sugiyono (1998) Statistika untuk Penelitian. Alfabeta. Bandung

Tjahjorini, Sri (2001). Persepsi Anak Jalanan terhadap Bimbingan Sosial melalui Rumah. Singgah di Kotamadya Bandung. Institur Pertanian Bogor

Walgito, Bimo (1981). Pengantar Psikologi Sosial. Indonesia: Andi Ofset Yusuf. A. (1991). Psikologi Sosial. Bandung:Remaja Rosdakarya 
